\title{
EVALUATION OF ARCHITECTURAL COMPONENTS IN BAYUNG GEDE VILLAGE SETTLEMENT, BALI AS A TOURISM OF SPECIAL INTEREST
}

\section{Ni Putu Yunita Laura Vianthi, I Dewa Gede Agung Diasana Putra}

Perencanaan dan Manajemen Pembangunan Desa dan Kota of Program Study (PMDK), Magister of Architecture Program Universitas Udayana, Bali, INDONESIA E-mail: laura.vianthi@gmail.com,diasanaputra@unud.ac.id

\begin{abstract}
Special interest tourism is one of the efforts to provide alternative tourist attractions and susta inable tourism development in Bali. Visits of both domestic and foreign tourists to Bali in the last 4 years (2015-2019) have increased by an average of $8 \%$. Now the tourism sector in Bali, especially in Bangli Regency, is starting to investigate or explore the possible development of tourist attractions through the development of tourist villages. In this case, the development of special tourism, including the tourist village of Bayung Gede, Bangli is very dependent on the architectural components of traditional settlements and the tra ditions of the residents in it a source of attraction and main attraction for tourists. However, the influence of tourism has led to the transformation of traditional settlements. In this case, the transformation has given rise to a paradoxical phenomenon where on the one hand tra ditional housing attracts tourists, on the other hand the presence of tourists has led to a transformation of the traditional settlements of an area. The purpose of this study is to examine the architectural components of the Bayung Gede Village settlement as a tourism potential based on special interest tourism and then to find out how far the tourism architectural potential is found and how strong the Bayung Gede Village settlement icon is as a special interest DTW. The method used is a qualitative-exploratory and descriptive method. The results show that the tra ditional settlement of Bayung Gede Village contains elements of special interest tourism such as elements of novelty seeking, qua lity seeking, enriching, rewarding, adventuring and learning, so that it has the potential as religious tourism (the existence of four types of graves), culture (settlement and residential layout) and citrus plantation sector agro-tourism in improving the economic sector of the community. Investigation and inventory of Bayung Gede traditional housing is an effort to find a village icon that has prestige that can attract tourists to visit and be able to com pete with other tourist villages.
\end{abstract}

Keywords: tourism village; traditional settlements; special interest tours.

\begin{tabular}{cccc}
\hline Received: & Revised: & Accepted: & Available online: \\
$2021-12-15$ & $2021-12-27$ & $2022-01-08$ & $2022-01-12$ \\
\hline
\end{tabular}

\section{INTRODUCTION}

The components of traditional architecture and special interest tourism are a unity of mutually supportive aspects where the presence of traditional houses can be the main attraction in a tourist area (Dewa Gede Agung Diasana Putra, 2019; Putra et al., 2019, 2020) especially special interest tourism areas. . The tra ditionalvilla ge feel supported by agriculture has offered the development of rural tourism, especially in developing countries (Phelan \& Sharpley 2011; Hossein, Alipour, and Da lir 2014). This tourism development model is supported by ecotourism, cultural tourism and agrotourism (Shushma 2012). However, this is still not getting enough attention in various tourist a reas, especially tourist areas that a re not well developed such as Bayung Gede Ban gli village. Along with the rapid development of tourism which is a sector that contributes to income The largest for the Province of Bali, now the tourism sector is starting to investigate or explore the possibility of developing a tourist attraction through the development of tourist villages which were initially thought to be unfit as a tourist attraction. It is known in Table 1 below through statistical data that foreign and domestic tourist visits to Bali in the last 4 years continued to increase before the Covid19 pandemic outbreak. 
Table 1. Data of Visits Domestic and Overseas for the Last 4 Years

\begin{tabular}{lll}
\hline Year & \multicolumn{1}{c}{ Number of Visits Domestic and Overseas } \\
\hline $\mathbf{2 0 1 6}$ & $\bullet$ & Domestic: 8.643 .680 \\
& $\bullet$ & Overseas: 4.927 .937 \\
\hline $\mathbf{2 0 1 7}$ & $\bullet$ & Domestic: 8.735 .633 \\
& $\bullet$ & Overseas: 5.697 .739 \\
\hline $\mathbf{2 0 1 8}$ & $\bullet$ & Domestic: 9.757 .991 \\
& $\bullet$ & Overseas: 6.070 .473 \\
\hline $\mathbf{2 0 1 9}$ & $\bullet$ & Domestic: 10.545 .039 \\
& $\bullet$ & Overseas: 6.291 .141 \\
\hline
\end{tabular}

Source: Central Bureau of Statistics of Bali Province, 2021

In Bali itself, one of the well-known tourism sectors is the traditional settlements commonly referred to as Bali Aga Villages/Mounta in Villages, such as Tenganan Village and Penglipuran Village. The village is a real example of a Tourism Village that has been recognized worldwide which is the prima donna of tourism in Bali, because the villa ge settlements have unique characteristics from the perspective of architecture. Penglipuran Village is the third cleanest village in the world. The villa ges a re very popular tourist destinations a mong both domestic and foreign tourists. The level of uniqueness is higher than other villages which causes this village to have such prestige. Based on this matter, it can be seen that settlements are an arrangement of building masses that are present as a result of a way that initially gather and settle together in certain dwellings, after that they are accustomed to living together or in groups which are based on close relationships or relatives, the same profession or social status. . Due to the implication between the morphology of the settlement and the characteristics of humans in their living activities, each settlement and house in the settlement has its own characteristics. This interpretation provides a representation that each settlement must have its own characteristics or uniqueness and can be developed into certa in sectors according to its potentialcharacteristics.

Bayung Gede traditional village is one of the villages which was inaugurated as a tourist village, in Bangli Regent Regulation No. 16 of 2014 (Bangli, 2014) regarding the determination of the tourist village area in Bangli Regency. This village holds and adheres to conventional norms and values that a re closely related to the traditional social numbers of its inhabitants. In this regard, the village of Bayung Gede has always consistently adhered to its customs without any outside influence so that it is bound by binding customary provisions. Awig-awig Bayung Gede Village is intended to maintain the perfection and sustainability of this village. The majority of this village work as farmers. His famous garden products include oranges, coffee, and corn. However, the majority of these villages are famous for their citrus plantations. There is a tendency for tourist village activities to visit or be captivated by nature, providing opportunities for Bayung Gede Villa ge to be developed into citrus and coffee agro-tourism in Kintamani. Bayung Gede Village which has a lot of potential both in terms of architecture, socio-culture and nature which can be directed in its development as a tourist attraction, especially cultural spiritual tourism and agro-tourism in supporting sustainable tourism development. 


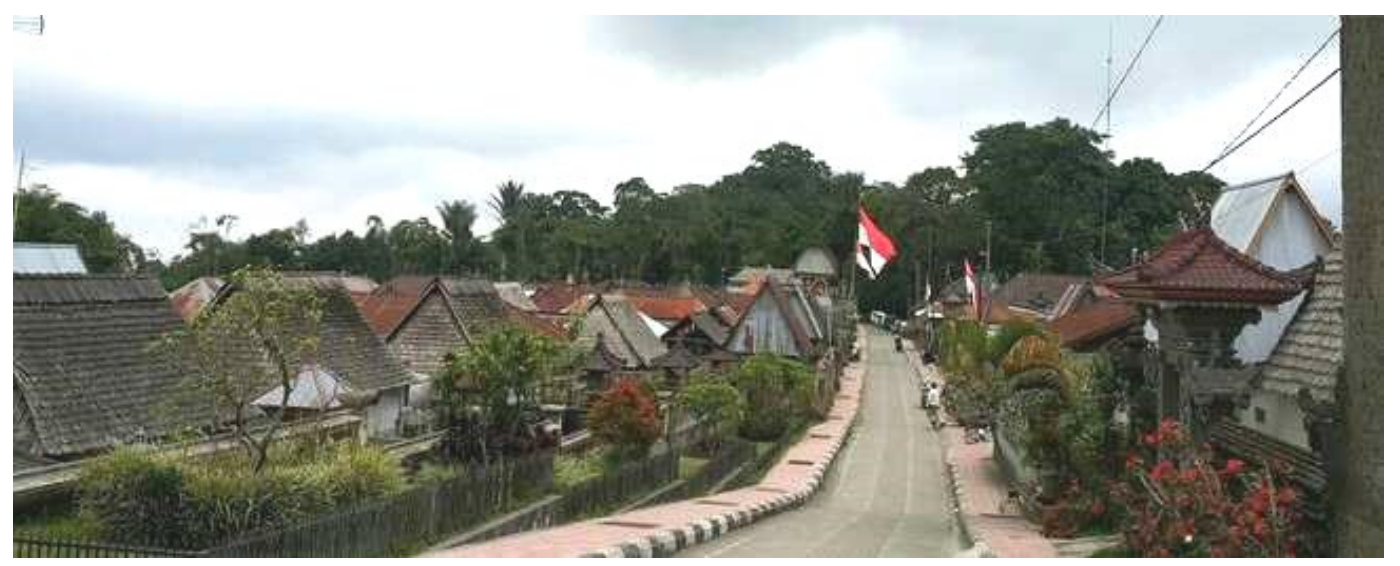

Figure 1. Settlement Patterns in Bayung Gede Village, Bangli Source: Vianthi, 2021

From an architectural point of view, the settlement pattern of Bayung Gede Village is also quite special (Dwijendra, 2009). Based on the results of the initial visit to the location, the majority of the spatial arrangement of houses in their settlements still maintains their settlement pattern. Even some of the mass buildings in the community's house compound are still standing as they were originally built. The specialty of the spatial arrangement of the settlement pa ttern of Bayung Gede Village is the pattern of the village arrangement and the layout of the house and the distinctive shape of the building. The layout of the settlements is neatly arranged and follows the concept of SpatialPlanning for Traditional Balinese Settlements as in Penglipuran and Tenganan Villages. The representation of the spatiallayout is that the Bayung Gede residential area is composed of rows of angkul-angkul as the entrance and the slope as a residential garden/landscape. Having special features/characteristics from an architectural point of view and the environmentalside of traditional architecture, culture and the products of citrus, coffee and corn plantations, gives a brief overview that this settlement has tourism potentialthat needs to be studied further, not just a study, but must be true. development is carried out.

Based on this, the natural and cultural diversity that exists in Bayung Gede Village can be a great ability in supporting special interest DTW. Special interest DTW has now become a tourism trend to a void mass tourism as an alterna tive to tourism. The encouragement of tourists to find something novel and have a classy tourist experience, presenting new innovations so as to increa se the demand for special interest tourists as a sustainable tourism development that utilizes the unique cultural landscape of an area (Adhika \& Putra, 2021; Aritama \& Putra, 2021). This paper focuses on evaluation through exploration and assessmentrelated to the architectural components of the Bayung Gede Village settlement which has tourism potentialbased on special interest tourism. The purpose of this study was to find data on the potential for DTW from the architectural components of the Bayung Gede Village settlement, then to find out how far the potential for tourism architecture was found and how strong the settlement icon of Bayung Gede Village was as a DTW of special interest. This research is also expected to help increase development in creating settlements that can accommodate Bayung Gede village as a special interest tourist village, so that the Bayung Gede Traditional Village Settlement can become a village icon that has a degree / prestige equivalent to Penglipuran Village which has been pinned as one of the 29 Bangli Tourism Villages in Bangli Regent Regulation Number 16 of 2014.

\section{RESEARCH METHODS \\ Research methods}

The method used in this research is qualitative with an exploratory approach and descriptive technique to describe some of the results from the data collected and then processed and concluded. The types of data used are primary data and secondary data. Primary data was obtained by direct observation, direct review and data collection by direct interviews with the informant, namely the head of Bayung Gede Village. Secondary data is obtained from literature such as similar journals and statisticaldata regarding data on domestic and foreign tourist visits in Bali for the last 4 years. 


\section{Place and time of research}

In Figure 2, the following is a map of the research location in Bayung Gede Village.

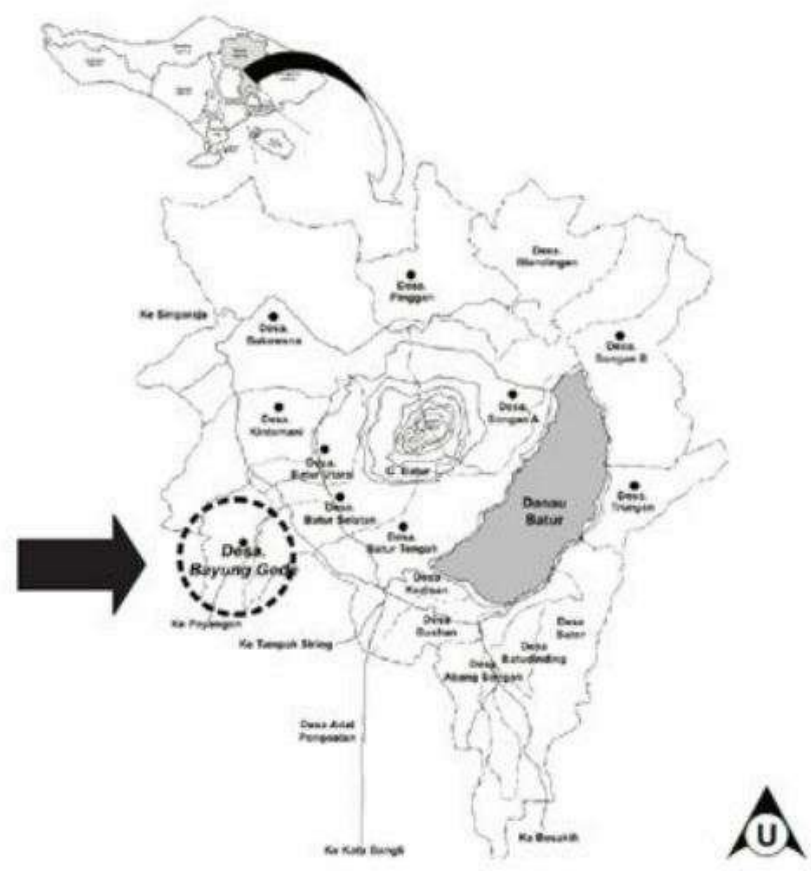

Figure 2. Location Map of Bayung Gede Village, Kintamani, Bangli. Source: BAPPEDA Bangli Regency, 2010

The research location is located in KintamaniDistrict, Bangli Regency, Bali Province, precisely in the ConventionalResidential Area of the Bayung Gede Traditional Village. This village is located in the western part of the Kintamani hills and Belancan hamlet, in the north it is bordered by the southern Baturhamlet, Sekaan and Bonyoh hamlets, while the eastern part is bordered by Sekardadi hamlet. The totalarea of this village reaches 1024 hectares, which is dominated by 931,6 hectares of land, 12 plantations, and more than 26 hectares of residentialareas, 2 hectares of landscaping, 1.2 hectares of offices, 32 hectares for other ordinary infra structure. (Dusun Monograph, 2013).

\section{Research design}

As described previously, this research question consists of 2 questions, namely:

1. What components of settlement architecture are contained in the Bayung Gede Village Settlement that can be used as potentialbased on special interest tourism?

2. How from an architectural point of view, the settlement icon of Bayung Gede Village can become a tourism object with special interest?

Based on these questions, this research uses a qualitative-exploratory method consisting of monitoring or observing the object of research and interviews. Qualitative methods were used to obtain in-depth and detailed information regarding the exploration and spatial analysis of the settlements of Bayung Gede Village, in order to a chieve findings on existing tourism potentials.

\section{Method of collecting data}

1. Observation

This research will investigate and study the architectural components of the Bayung Gede Village settlement that have the potential to become a special interest tourism village. In this case, it is necessary to carry out physical data collection through observation with the senses. 
This research is exploratory through observation to obta in the essential points of the architectural components of the Bayung Gede Village settlement which are still thick with Balinese Tra ditional Architecture or the spatial cha racteristics and forms of the buildings which are special and essential with local characteristics.

Observation is assisted by tools such as cameras and notebooks. By observing every aspect of the architectural component of the settlement, it can be record ed properly, so that the exploration of the components can be categorized. Implementation of observations by recording the layout, shape, decoration and others from the settlement and each house.

2. Interview

The collection of interview data was carried out with non-physicaldata, in the form of supporting data in the form of stories behind the a rchitectural components of settlements that have tourism potentialand the daily activities of residents who have unique characteristics and certa in cultural customs. Where later these stories provide a meaning/value for the physical objects found, so that they can become icons for the settlements of Bayung Gede Village. The target of the interview will be to the village's policy makers, namely the jero kebayan of Bayung Gede Village.

\section{Questionnaire}

The collection of questionnaire data is carried out with an array of questions that lead to whether or not the research findings a re a special interest tourist attraction using the google form platform electronic media. This method is used to a void the spread of the Covid-19 virus during the current pandemic.

\section{Research flow model}

The following table 2 is the stages of this research flow.

Table 2. Research Flow Process for Bayung Gede Village Settlement as Special Interest Tourism

1. Data: Increase in the number of domestic and foreign tourists visiting Bali

Issue: Designation of Bayung Gede Village as a Tourism Village, but to reduce mass tourism, it is necessary to study special interest tourism and plantation tourism, which have great potential in tourism development.

2. "EVALUATION OF ARCHITECTURAL COMPONENTS INBAYUNG GEDE VILLAGE SETTLEMENT AS A SPECIAL ATTRACTION OF INTEREST.

3. Formulation of the problem:

- Residential architectural components as special interest tourism potential

- Elevating tourism potential to become a special interest tourism icon

4. Literature review

- Special Interest Tourism Village Concept

- Architecture and Tourism

5. Method: Qualitative-Explorative

6. Indicators: morphology, value/meaning, environmentalelements

7. Findings

8. Results and Discussion (Data Analysis)

9. Conclusion

Data analysis 
The data from observations, interviews and questionnaires were then processed, analyzed, with the first stage grouping physical and non-physicaldata assisted by categorization (coding) to facilitate the next stage of analysis. Then the second stage is assisted by using tourism and architecture theory and the third stage is interpreting/perception based on the previous analysis and the fourth stage as a conclusion so as to find the results of the phenomena raised in the study.

\section{Research Indicators}

The following can be seen in Table 3 which are research indicators that will be used in relation to the goals and objectives of this research, namely:

Table 3. Research Indicators of Bayung Gede Village as Special Interest Tourism

\begin{tabular}{|c|c|c|}
\hline Dimension & Indicator & Description \\
\hline \multirow[t]{4}{*}{$\begin{array}{l}\text { Distinctiveness of } \\
\text { the Settlement } \\
\text { Architecture } \\
\text { Components of } \\
\text { Bayung Gede } \\
\text { Village as a } \\
\text { special interest } \\
\text { tourism }\end{array}$} & Morfology & $\begin{array}{ll}\text { - } & \text { Settlement pattern } \\
\text { - } & \text { Spatiala rrangement } \\
\text { - } & \text { Building mass composition } \\
\text { - } & \text { the shape of the building mass } \\
\text { - } & \text { building mass materials } \\
\text { - } & \text { decorative mass of the building }\end{array}$ \\
\hline & Value/meaning & $\begin{array}{l}\text { - traditionalarchitecturalconcepts that are still embodied } \\
\text { - } \\
\text { stories/origins of settlements and the existence of } \\
\text { neighborhoods and community houses }\end{array}$ \\
\hline & $\begin{array}{l}\text { environmental } \\
\text { elements }\end{array}$ & $\begin{array}{ll}\text { - } & \text { Naturalelements } \\
\text { - } & \text { Human element } \\
\text { - } & \text { Socio-cultural elements } \\
\text { - } & \text { Network element } \\
\text { - } & \text { Place element }\end{array}$ \\
\hline & $\begin{array}{l}\text { Special interest } \\
\text { tours }\end{array}$ & 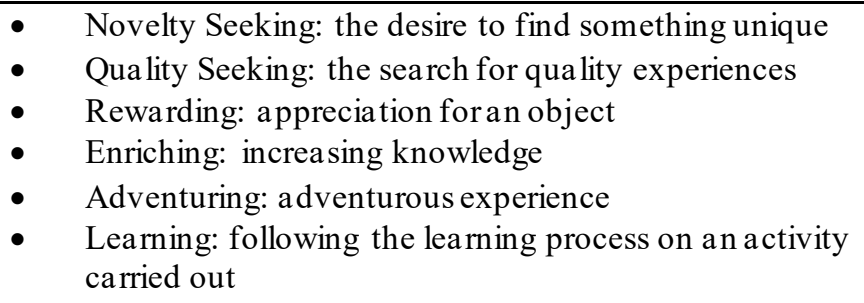 \\
\hline
\end{tabular}

\section{RESULTS AND DISCUSSION}

\section{The Existing Condition of the Bayung Gede Village Traditional Settlement}

As a Bali Aga village, the zoning division of the village area is strongly influenced by the beliefs of the population and its geographical location where the zoning, like other Bali Aga villages is an area with a linear pattern (Parimin, 1986). As can be seen in Figure 3, the following is a zoning division consisting of 3 zones, namely orange is the main zone (sacred area) such as a temple, then purple and green are the middle zone (original yard/residential housing) and plantation or development areas and residential areas and the third is the dirty/dirty zone, which is like a graveyard area. 


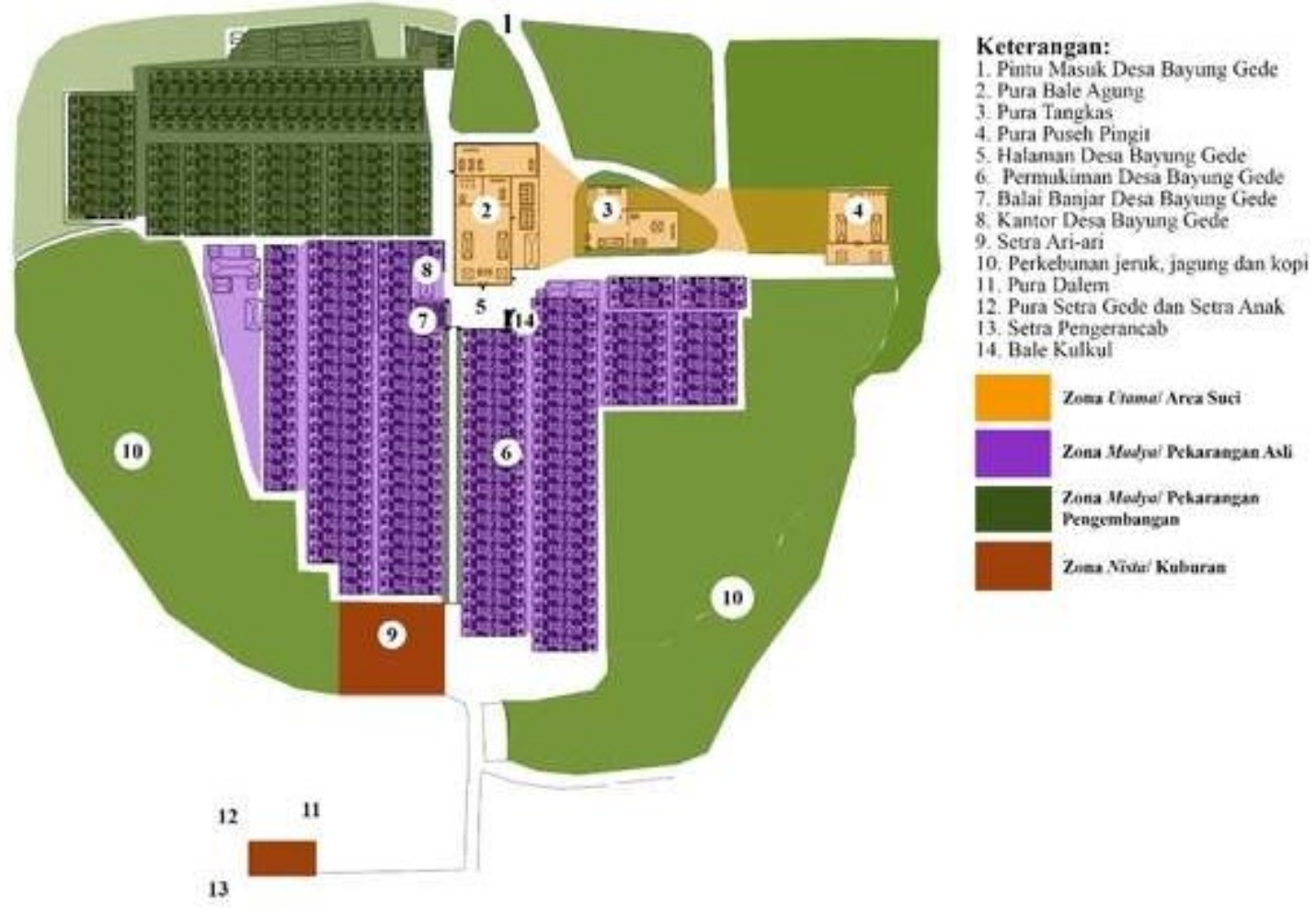

Figure 3. Zoning of the Bayung Gede Village Residential Area, Bangli

The image above is sourced or created by the author.

Description:

1. Bayung Gede Village Entrance

2. Bale Agung Temple

3. Tangkas Temple

4. Puseh Pingit Temple

5. Bayung Gede Village Courtyard

6. Bayung Gede Village Settlement

7. Bayung Gede Village BanjarHall

8. Bayung Gede Village Office

9. Setra/Ari-ari Graves

10. Citrus, corn and coffee plantations

11. Pura Dalem

12. Pura setra big and setra children

13. Scavenger's Grave

14. Bale/wantilan kul-kul

Orange color: main zone (sacred area/temple)

Purple color: middle zone (residential)

Green color: middle zone (plantation)

Red color: dirty zone (grave)

Figure 4 below shows the existing facilities in the Bayung Gede Village settlement, where the first a rea is the village entrance (temple bentar) which is indicated by picture number one, then the second is Bale Agung Temple, the third Tangkas Temple, then there is an a rea village parking, settlements in Bayung Gede Village, BanjarHall, Village Office, Grave Area, Plantation Area, Wantilan Balai Kulkul and Bayung Gede Tourist Post/Loket. 


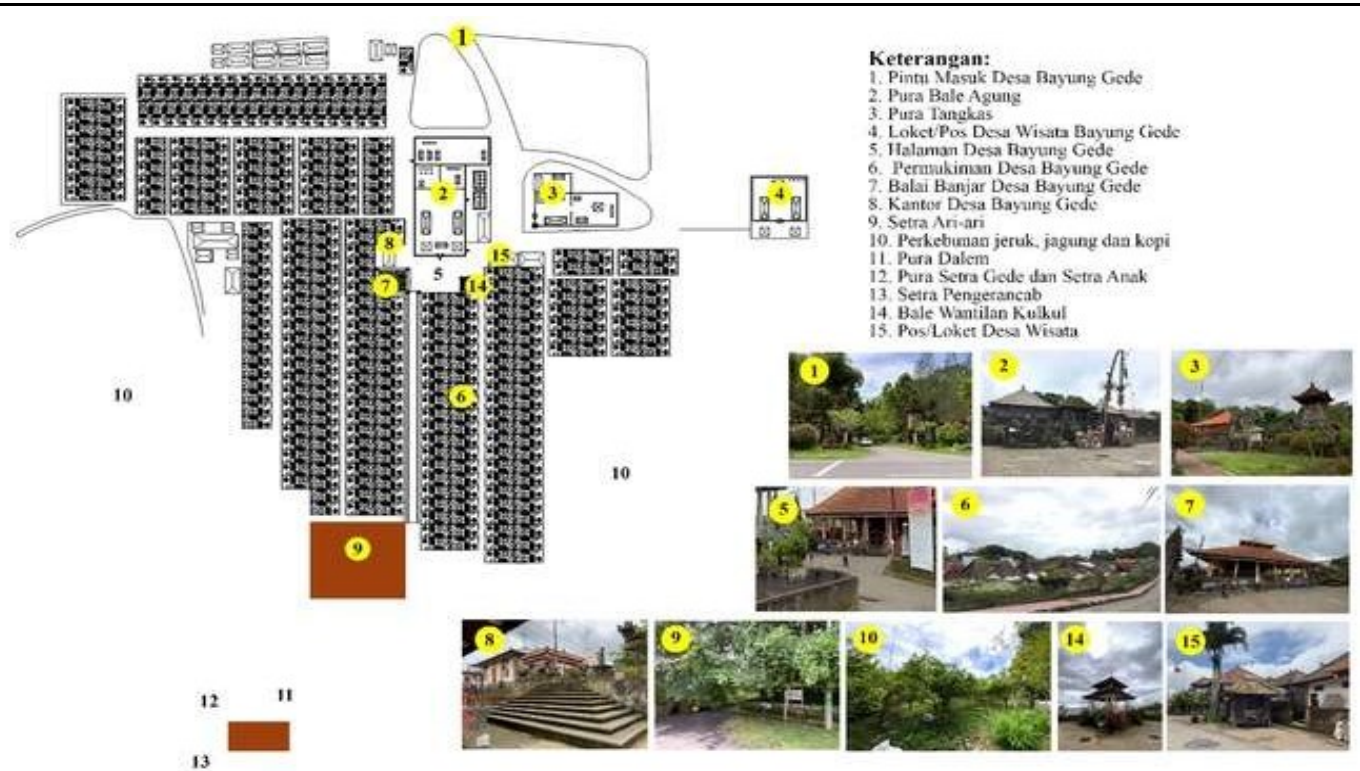

Figure 4. Existing Layout of Bayung Gede Village Settlement in 2021. Source: Vianthi, November 2021

The image above is sourced or created by the author.

Description:

1. Bayung Gede Village Entrance

2. Bale Agung Temple

3. Tangkas Temple

4. Puseh Pingit Temple

5. Bayung Gede Village Courtyard

6. Bayung Gede Village Settlement

7. Bayung Gede Village BanjarHall

8. Bayung Gede Village Office

9. Setra/Ari-ari Graves

10. Citrus, corn and coffee plantations

11. Pura Dalem

12. Pura setra big and setra children

13. Scavenger's Grave

14. Bale/wantilan kul-kul

15. Post/counter for the tourist village of Bayung Gede

\section{Elements of the Bayung Gede Village Settlement Environment}

Conventionalor traditional housing or settlement is a place to live with a conventionalsystem with area features within the framework of local traditionaltraditions (Gelebet, 1986). For K. Basset and John R. Short (1980), residential area is a system consisting of 5 parts, namely Nature (natural factors), covering natural energy sources such as topography, hydrology, soil, air, or biological factors. are vegetation and fauna; Man (person as a person), covers all his personal desires such as biology, full of emotions, moral values, feelings, and perceptions; Society (citizens), the presence of people as a group of citizens; Shells (places), where people as individuals or groups carry out activities or carry out life; Network (network), is a naturalor human-made system, which supports the functioning of the residential area such as roads, clean water, electricity, and the like. The following describes the environmentalelements found in the Bayung Gede Village Settlement:

\section{Nature (Elements of Nature)}

This village is located in a mountainous area, located in the western part of the hilly area of Kintamani, on the north side it is bordered by Dusun BaturSelatan, Dusun Sekaan, Bonyoh south, 
Dusun Sekardadi east and west Dusun Belancan. This hamlet has a size of $\pm 1,024$ ha which is dominated by 931,6 hectares of plantation land, and more than 26 hectares of settlements, 2 hectares of landscaping, 1.2 hectares of offices, 32 hectares for other ordinary infrastructure. (Dusun Monograph, 2013)
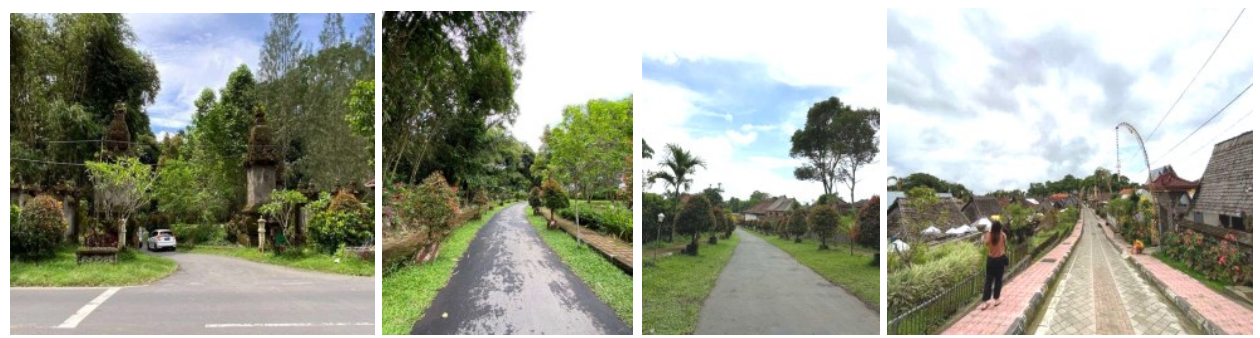

Figure 5. Main Village Gate, Entrance to Village, Village Settlement Source: Vianthi, November 2021

In Figure 5 above is a picture of the main gate entering the village, then the village landscape area and existing vegetation as a guide to the main area of Bayung Gede Village and village settlements. The arrangement of the landscape area towards the villa ge in the form of the first open space as a guide to the Bayung Gede Tourism Village further adds to the authenticity of the rural nature. Figure 6 below shows the spatial characteristics of Bayung Gede Village, as a result, it proves that this village has a special rule of traditionalvillage form, so that it can show a beautiful rural face with strong customs. The arrangement of the morphology or form of the village is bound by the customs of the community which have been officially passed down from generation to generation. Judging from the picture below, entering the residential a rea through the bamboo forest (tegal suung), then arriving at the gathering point, there is a sacred area located in the main zone, then the middle zone of the settlement and the humilia ting zone, namely the cemetery area.

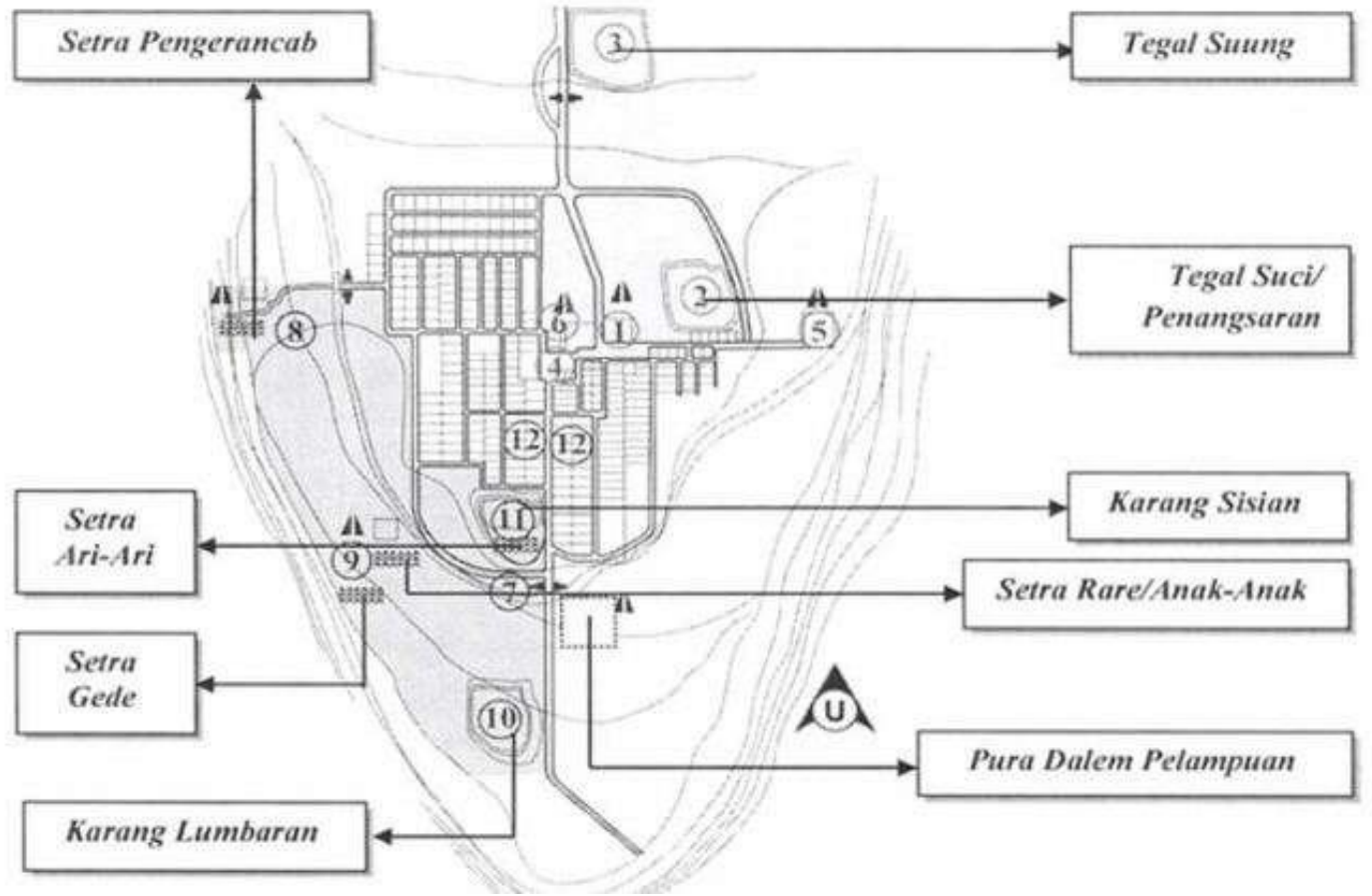

Figure 6. Spatial Bayung Gede Traditional Village. Source: Modified from Tamiartha, 2003

As can be seen in Figure 7, the following is a characteristic of a unique place element in the form of a setra placenta (grave), in this area there is a bungkak tree where the fruit produces sap which 
is used as an area to put the placenta following a custom that has long been carried out for generations.
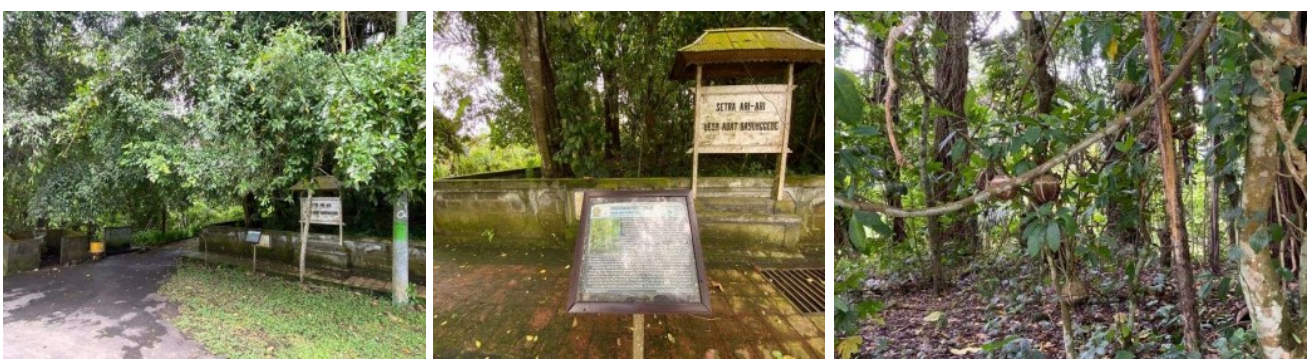

Figure 7. Setra Ari-ari in Bayung Gede Village. Source: Vianthi, November 2021

Bayung Gede Village is one of the villages that produces Kinta mani oranges, which are well known to the local, regional and international community. Bayung Gede Village produces superior a gricultural products other than oranges, namely local white corn, the cobs reach a length of $30 \mathrm{~cm}$, the seeds are white and shiny, with a delicious taste, a little sticky, but lately its existence has been very rare, this matterneeds to be tested for security and raised as a distinctive characteristic of the product. favorite Bayung Gede Village, in an effort to support the development of the Bayung Gede tourist village as tourism with a special purpose. It can be seen in Figure 8 is an orange plantation from Bayung Gede Village.
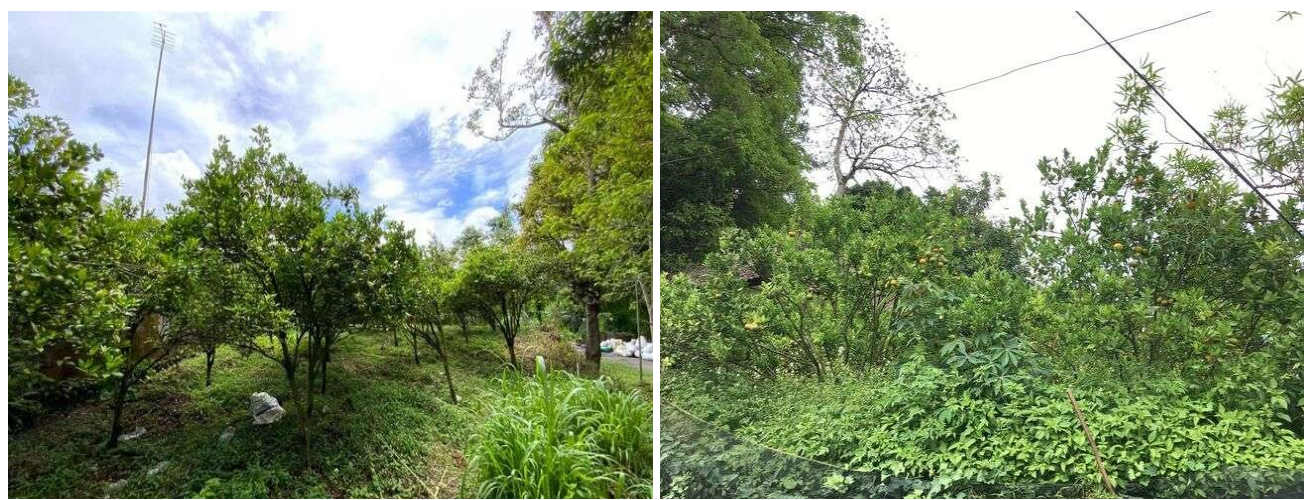

Figure 8. Orange Plantation in Bayung Gede Village. Source: Vianthi, November 2021

Besides, based on the results of a question and answer session with Jero Kubayan Bayung Gede, he said that this village has a special favorite product, namely Banana Ba li, this banana tastes delicious, about sweet, in the past this banana was commonly eaten for baby food. The presence of Balinese bananas is starting to be vulnerable from the spread of stem rot disease in banana plants, this requires security measures to avoid the scarcity or extinction of Balinese bananas as a favorite agricultural product of Bayung Gede village in an effort to support the development of the village as a tourist destination.

\section{Man (The Human Element)}

The individual's life is conventional and always upholds the customary law of the village, always advancing the principles of a lliance, unity and togetherness. This is because each community has a responsibility to protect the susta inability and sacredness of the village. The number of people in the village of knife carving Besar is 2041 people with 501 families consisting of 1045 men and 955 women. The majority of the people from the hamlet of knife carving Besar live as farmers. The following is Figure 9 conducting an interview with a village leader, namely Jero Kubayan. 


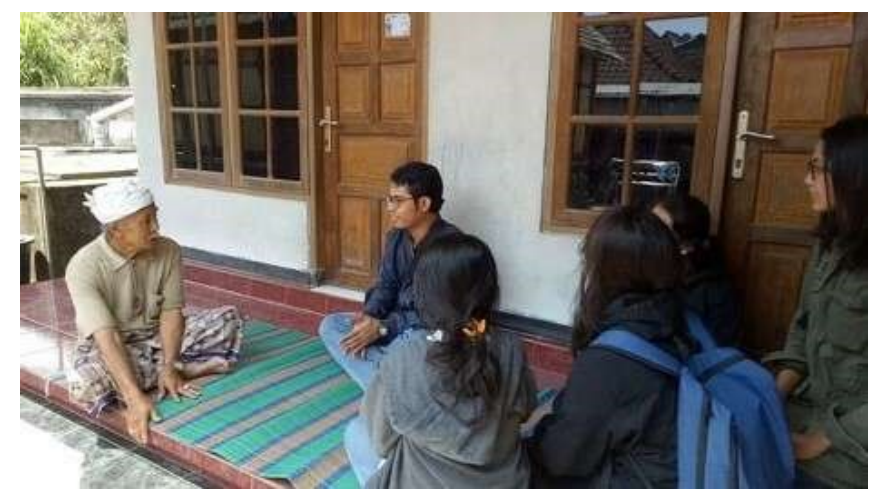

Figure 9. Interview with Jero Kubayan (Village Leader), 2018. Source: Vianthi, 2018

Most of the residents of Bayung Gede villa ge live or carry out their daily activities as farmers, the most famous field products in this area are oranges, coffee, various types of vegetables and fruit including corn. The people of Bayung Gede Village, use a special calendar or calendar made of frames to determine good days in ceremonialactivities or in a griculture such as good days for sowing or when picking. The results of farming can fulfill the biological desires of the Bayung Gede hamlet community. Bayung Gede village does not understand the existence of group chess or color chess, there are no frills of the nicknames Ida Baik, Anak Agung, I Sultan, I Dewa or Cokorda in the nicknames of the people here. This is indeed a characteristic of the customs of the ancient Balinese people because they existed before the impact of knights or colors that entered Bali. (Dwijendra, 2009; T. Reuter, 2002; T. A. Reuter, 1996).

\section{Society (Elements of Society/Culture)}

Society is a unitary group of people or families in a residential area that forms a specialcommunity. Circumstances related to community life living in the Bayung Gede Village area include:

1. Observed in Figure 10 below is the "ulu apat" (customary village form) pattern of leadership system originating in very old family heads, namely Jero Kubayan Mucuk and Jero Kubayan Nyoman. After that, under the previous 2 directions there are also known as Jero Bau Mucuk and Jero Bau Nyoman. Jero Kubayan worked to preside over the implementation of traditional and religious ceremonies, while Jero Bau was Jero Kubayan's aide. The four pairs of families were free from all forms of dedosan (compensation) from the village.

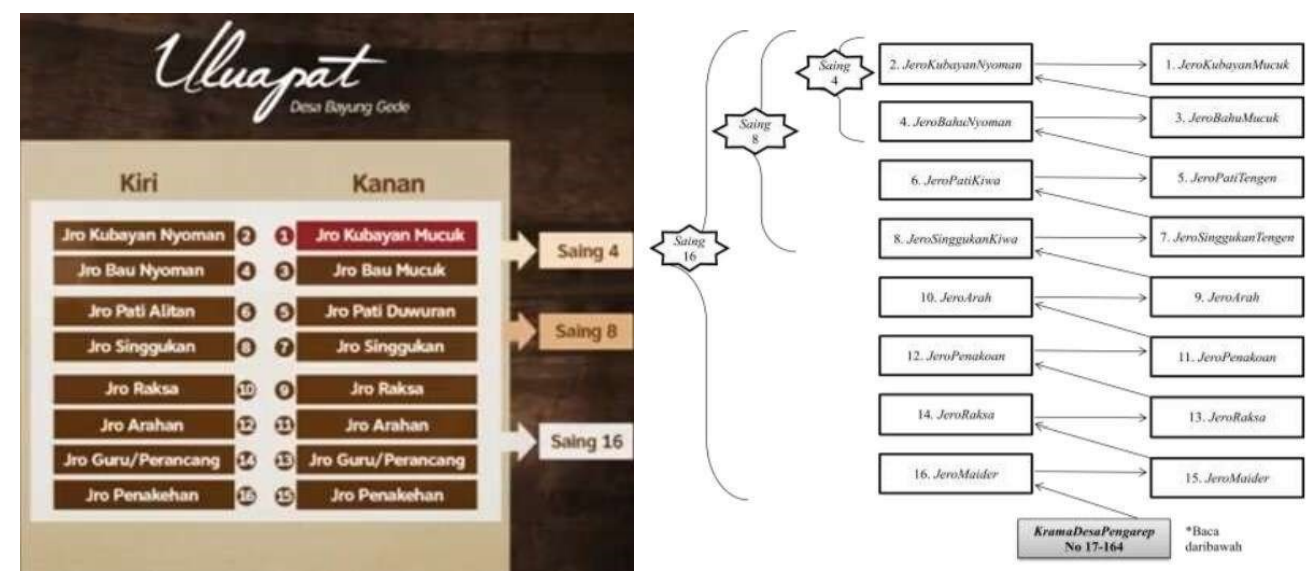

Figure 10. "Ulu Apat” Governance Pattern in Bayung Gede Village. Source: Nugrahaningari, et al, 2017

Another culture found in Bayung Gede Village is the tradition of "Suren War" which is held every 5 years, to be precise at the work / piodalan ngusaba Lampuan at Dalem Lampuan Temple. The participants of this suren war tradition are young people who have grown up. This suren war is very 
similar to the pandanus war in Karanga sem and the banana midrib war in Bangli. The only difference is the tool. Seen in Figure 11, the tools used in the suren war are tools taken from the suren tree.

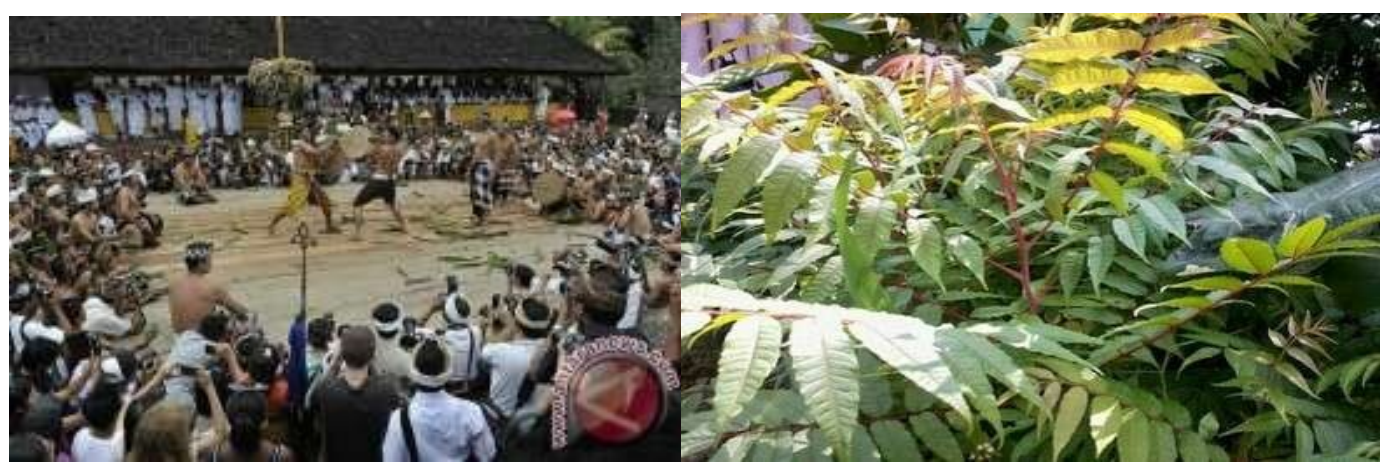

Figure 11. The Suren War Tradition in Bayung Gede Village. Source: Antara Bali, November 2011

Every community in Bayung Gede Village who gives birth, the placenta is hung on a bungkak wood area which is called the placenta. Because if it is placed or buried at home, people believe that the yard of the house will be dirty/disgracefully. It can be seen in Figure 12 is the tomb of the placenta in the settlement of Bayung Gede Village.
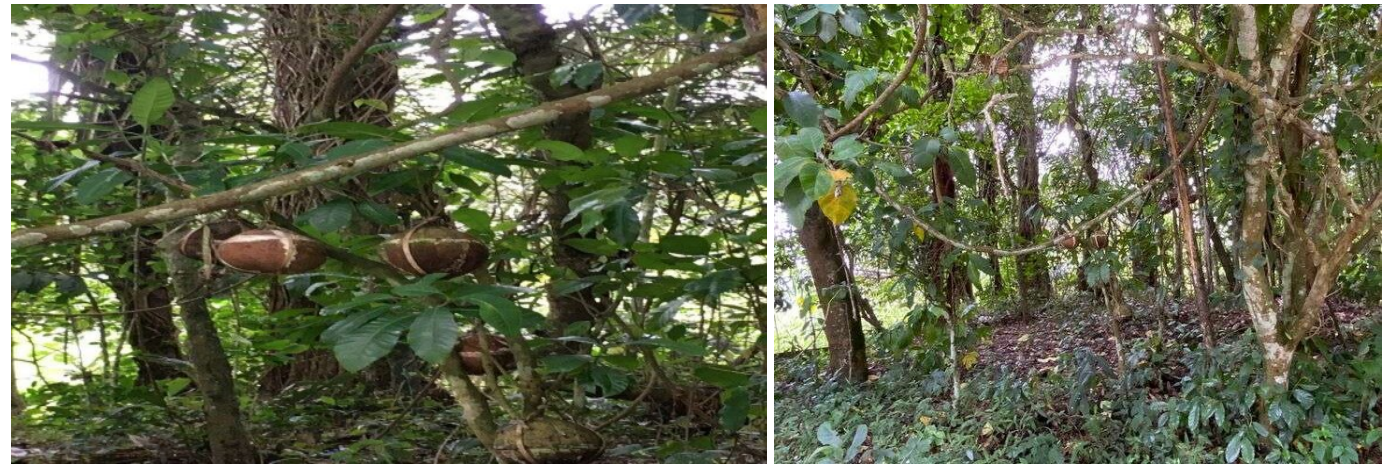

Figure 12. Cemetery of the placenta in Bayung Gede Village. Source: Vianthi, November 2021

1. Men who are from outside the Bayung Gede Village who want to marry a woman from Bayung Gede Village are required by both partners, both men and women, to donate a dowry in the form of two cows which are given to the people of Bayung Gede Village.

2. The majority of the people of Bayung Gede Village are in their plantations from morning to evening, after that they return to their respective homes. However, when there is a religious ceremony they will contribute to its implementation at the village center.

3. Bayung Gede residents are not a llowed to practice polyga my, because customary village rules are prohibited and if anyone violates they are given a sanction by being dismissed from the village and there has been an incident related to this, forcing them selves to stay in this village and finally getting a disaster.

4. For residents who practice polygamy, they must choose a house to live in a downstream or lowland area located to the west or south of Bayung Gede Village in the form of a hut for residents who are often polygamous "peludu". This tradition is to educate men to be faithful to one partneronly.

\section{Shells (Place)}

It can be seen in Figure 13 the layout of the mass of buildings and the peculiarity of traditional houses in the tra ditionalvillage of Bayung Gede is the arrangement of the mass of buildings in rows, 
where the road is the orientation of the residential layout. In the Bayung Gede residence there are several mass buildings such as: (1) angkul-angkul/kori; (2) Jineng; (3) safety bale; (4) paon; and (5) rebuttal/holy place.

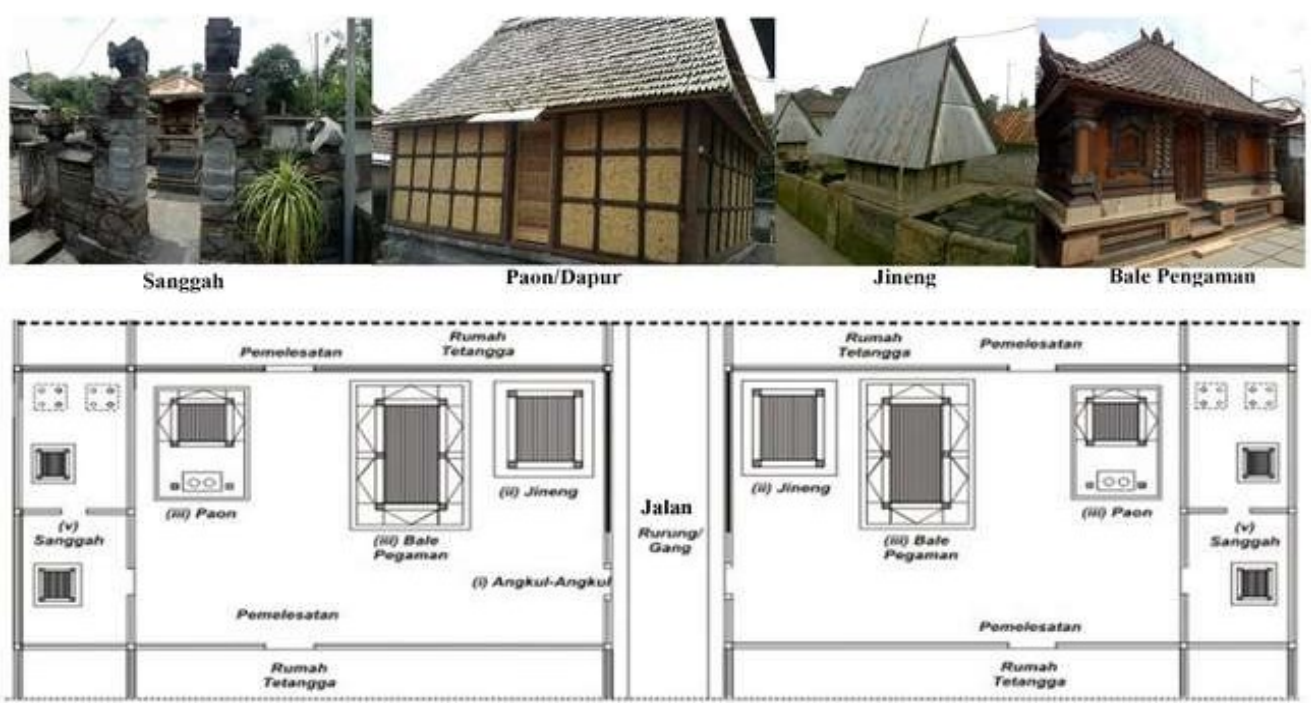

Figure 13. Layout of Residential Shells in Bayung Gede Village Settlements. Source: Vianthi, November 2021

Description:

(i) Angkul-angkul: as the entrance

(ii) Jineng: as a place to store rice granaries

(iii) Safety bale: as a place to rest/sleep

(iv) Paon/Kitchen: as a cooking area

(v) Refutation/temple: as a place of worship/worship of God

\section{Network}

The following can be seen and observed the description of the facilities and infrastructure available in the Bayung Gede TraditionalVillage, Bangli.

\section{Facilities}

Can be seen in Figure 14 is the master plan of Bayung Gede Village, there are several facilities in Bayung Gede Village. These facilities consist of trade economic service facilities such as shopping areas, social facilities that support education and health, social welfare service facilities such as places to hold religious ceremonies and government offices, as well as supporting facilities such as the application of green open spaces (landscapes).

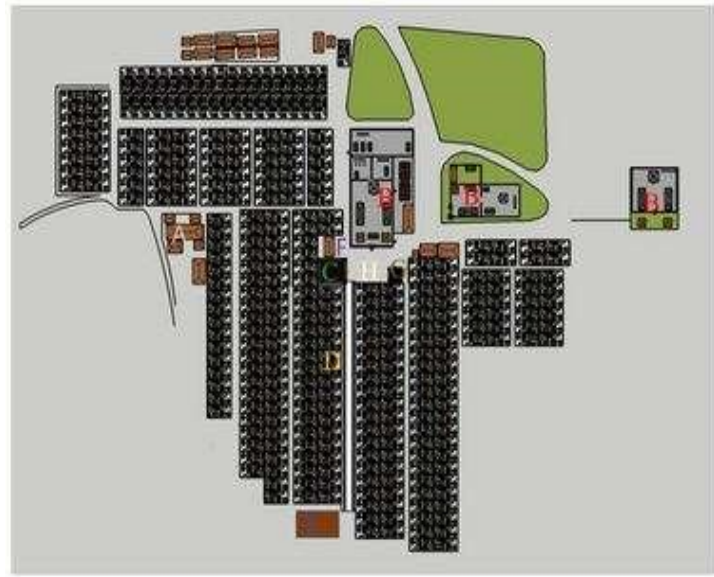

KETERANGAN

A: SDN Bayung Gede
B: Tempat Suci (Pura)
C: Bale Banjar
D: Warung
E: Setra Ari-Ari
F: Kantor Perbekel Desa Bayung Gede
G: Bale Kul-Kul
H: Parkir



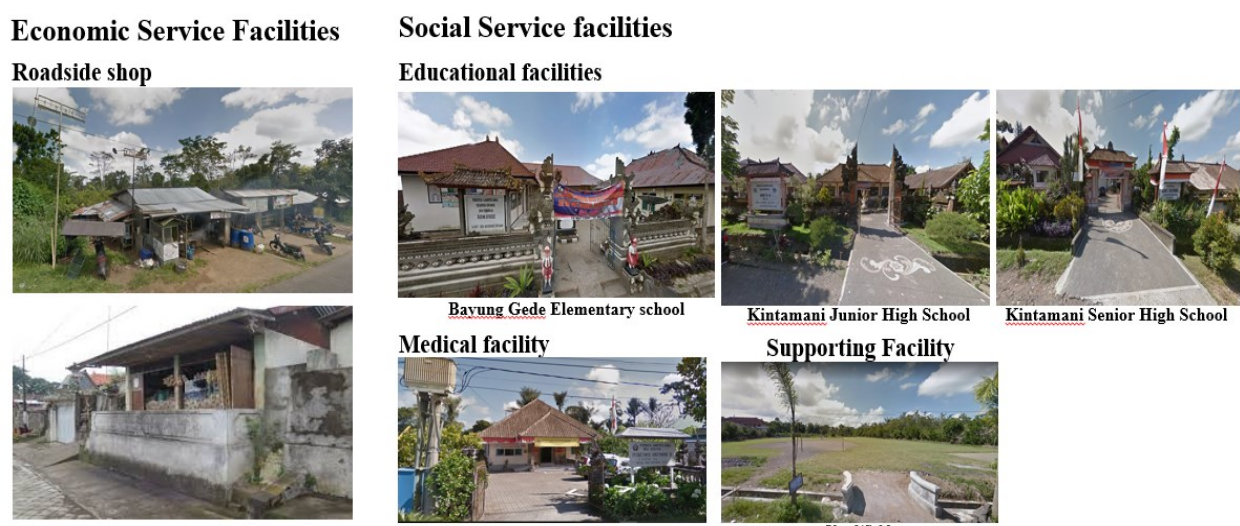

Supporting Facility

Kintamani Senior High School

Kintamani VI: Public health center
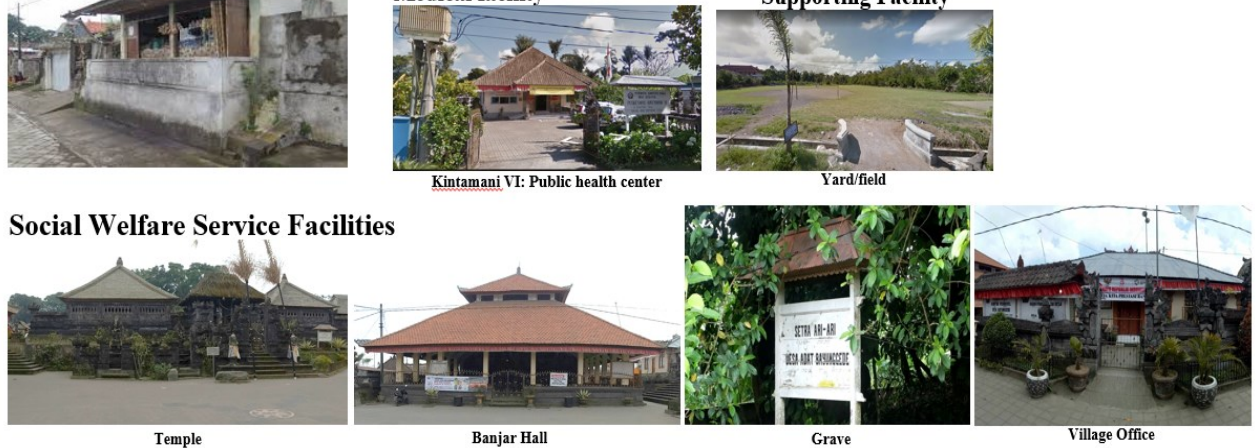

Figure 14. Aspects of Bayung Gede Village Facilities. Source: Vianthi, November 2021

\section{Infrastructure}

The infrastructure in Bayung Gede Village is more functioned to support the daily activities of the local community. For example, the existence of infrastructure that supports the accessibility/mobility of humans and vehicles, the existence of supporting infrastructure for cleanliness, the existence of clean water infrastructure, the existence of supporting infrastructure for telecommunications, as well as the existence of infrastructure for energy sources used by the community.

It can be seen in Figure 15 that the existing infrastructure in Bayung Gede Village includes:

- Collector road, which is a city connecting road between Bayung Gede Villages.

- Secondary local road I, which in the picture below is secondary local road I in Bayung Gede Village, connects access between collector roads and secondary local roads II and activity centers on secondary local roads I such as Tangkas Kori Agung Temple, Bayung Gede Village, Kahyangan Temple Three, Bale Banjar, Bayung Gede Village Repair Office. For the road width on the secondary local road $\mathrm{I}$ is \pm 8 meters with a sidewalk width of \pm 1.5 meters and the distance between intersections is approximately $>200$ meters.

- Secondary road II is a road that connects access to secondary local roads III and connects activities to roads that are higher in the hierarchy. In the picture below is secondary road II in Bayung Gede Village. The secondary road II in Bayung Gede Village connects access between secondary local roads I with secondary local roads III and the center of activity with other facilities on secondary local roads II such as the placenta and SD N Bayung Gede. The width of the road on the secondary local road II is \pm 6 meters with a sidewalk width of \pm 1.5 meters and the distance between intersections is approximately $>200$ meters.

- Environmental roads are service roads in residential a reas with state-owned land status and public infrastructure. In the picture above is an environmentalroad in Bayung Gede Village that connects to the houses of residents of Bayung Gede Village settlements. There are 2 types of environmental roads in Bayung Gede Village, namely the first with the width of the environmental road I of approximately \pm 2.5 meters and the second the width of the environmentalroad II of approximately \pm 1.5 meters. 


\section{PARKING}

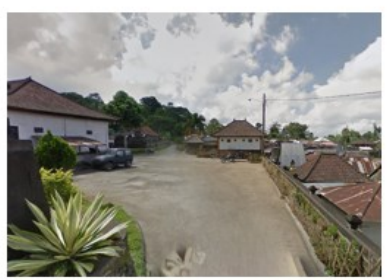

NETWORK

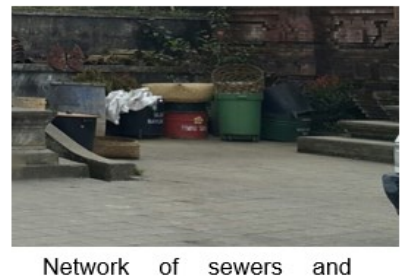

landfills
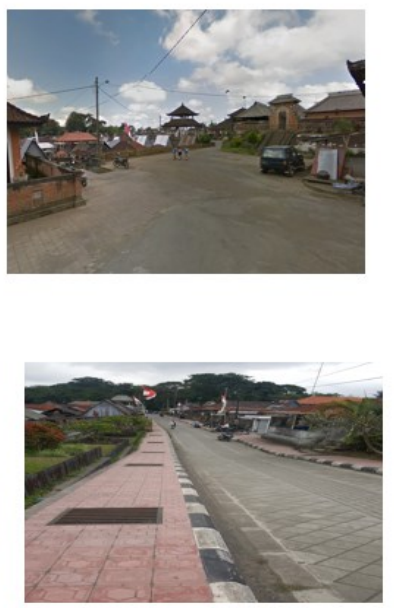

Rainwater channel network for local flood control/ drainage and prevention

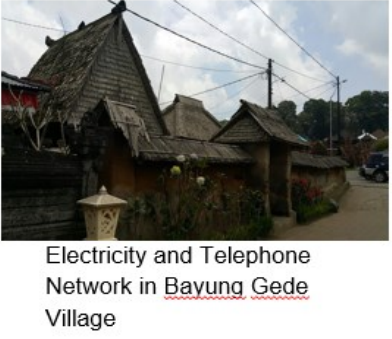

Village

Figure 15. Infrastructure Aspects of Bayung Gede Village. Source: Vianthi, November 2021

\section{Bayung Gede Village Settlement Layout}

The Bayung Gede Village Settlement is an original Balinese age settlement adhering to Traditional Ba linese Architecture (ATB). Spatialplanning related to the Bayung Gede Village Settlement shows the characteristics of a unique and interesting spatialpattern as well as the persistence of the spatial layout of its traditionalsettlements. This resilience is shown in detail by the preservation of spatial elements of traditionalBalinese settlements, such as:

\section{Settlement Pattern}

Bayung Gede Village is a settlement that adheres to a linear pattern. One example of a village with a well-known linear settlement pattern is Penglipuran Village in Bangli Regency.

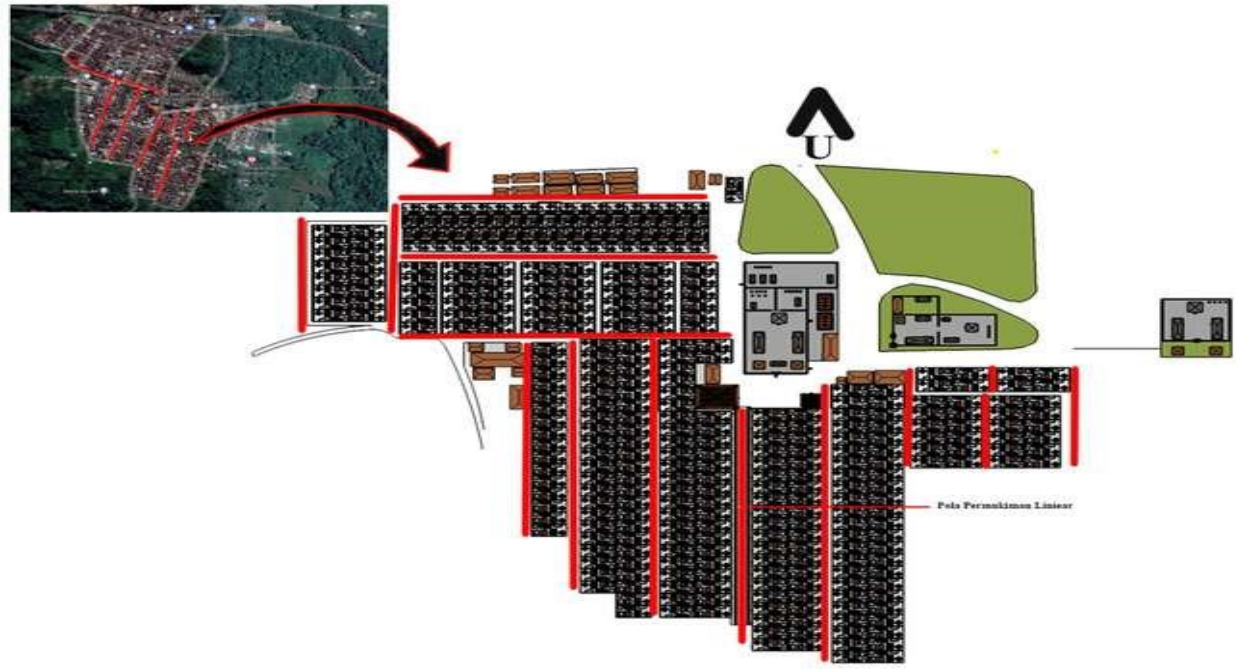

Figure 16. Linear Settlement Patterns in Bayung Gede Village. Source: Vianthi, November 2021

The linear pattern of this settlement is shown in Figure 16 above, with 1 road, namely Jalan Melati which is the orientation of the opening or entrance (corridor) of the residents' yard. Another a spect that reinforces the traditional linear pattern is at the intersection of the road on the north-south side 
(Kaja-Kelod) of the settlement, there is Pura Bale Agung. Bale Agung Temple is a sacred place for residents to pray in the Bayung Gede Village Settlement area.

\section{Landscape (Telajakan) Settlement}

Telajakan can also be referred to as elements of traditional Balinese landscape architecture. Telajakan is actually one of the concepts of Traditional Ba linese Green Open Space (RTH) which refers to the Tri Hita Karana philosophy, to achieve happiness in life through establishing a harmonious relationship between Human-God-Environment. It can be seen in Figure 17 below, which is the Tejakan in this Bayung Gede Village Settlement measuring $120 \mathrm{~cm}$ wide. Telajakan is also planted with various Balinese vegetation such as puring (plawa), plumeria (Japanese) Bali, sandat, red shoots, ornamental plants and grasses. The variety of vegetation previously mentioned is mostly classified as vegetation that is able to support the sustainability of the customs of the Bayung Gede community, especially in the a spect of upakara (infrastructures of offerings to God). Judging from the variety of vegetation, planting functions, and visuals, the bayung Gede settlement looks very tra ditional in terms of visuals and functional in terms of plan ting purposes. Re-examining the benefits of Tri Hita Karana's philosophical a ssessment as a supporting element of environmental quality. With the survival of the trail, the beauty and health of the environment (provider of oxygen and absorbent of carbon dioxide) can be maintained.

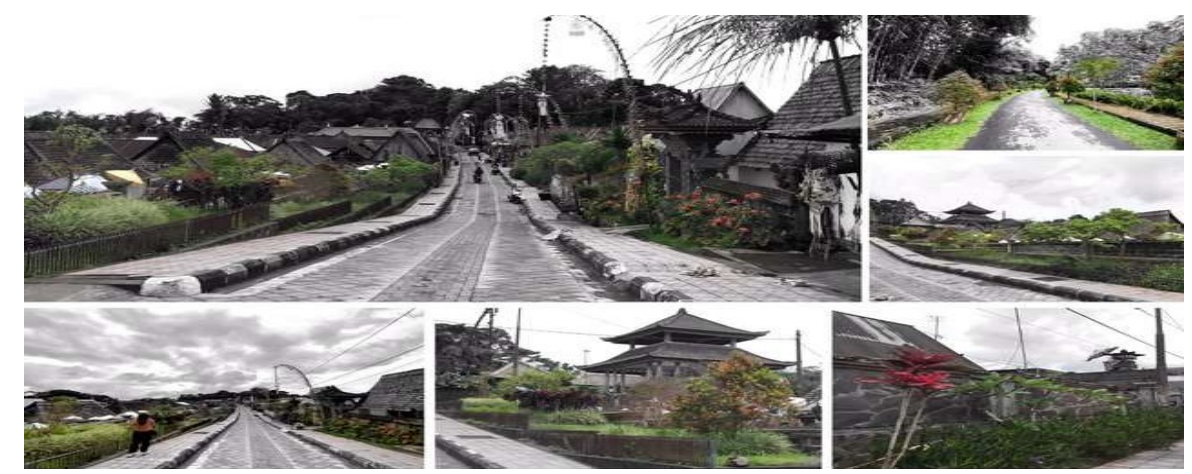

Figure 17. Tra ditional Ba linese Landscape/Garden Settlement in Bayung Gede Village. Source:

Vianthi, November 2021

\section{Kori or Angkul-angkul (Entrance)}

Kori / Angkul-Angkul is an architectural element of the traditional Ba linese entrance that leads to the residents' yard. It can be seen in Figure 18 below, the majority of angkul/kori have changed shape or form. In terms of form and material, some of the kori have been renova ted to be bigger to show an increase in social status, while others still mainta in the initial form they were built. Most of the Kori buildings are shaped or carved using the "bebadungan" concept, but using brick material and plastered with cement. Overall, Kori's layout is still in the position it was originally built. There are two types of angkul-angkul, the first angkul-angkul is still as it was originally built and the second angkul-angkul that has been renovated with brick material then plastered with cement and shaped.

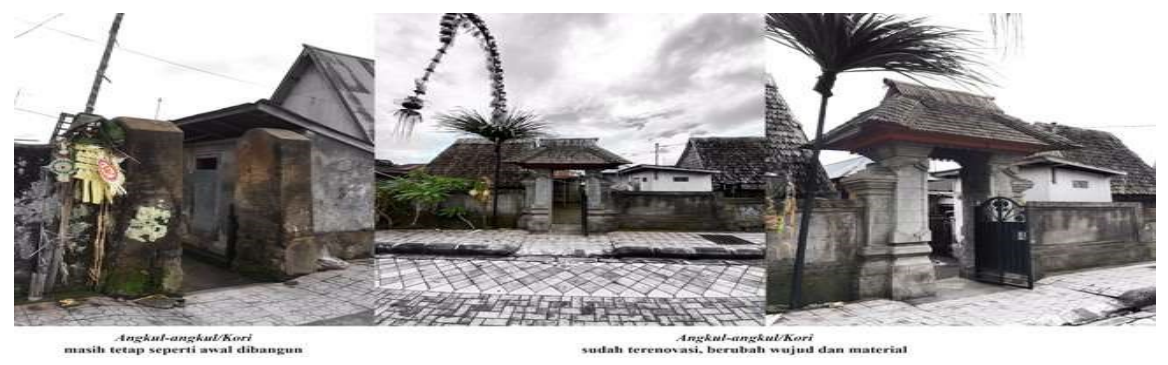

Figure 18. Angkuls in the yard of the house in the Bayung Gede Village Settlement. Source: Vianthi, November 2021 


\section{Description:}

1. Angkul-angkul/kori are still the same as when they were built

2. Angkul-angkul/kori have changed shape and material

\section{Spatial Layout and Condition of Building Mass for Bayung Gede Villagers}

Based on the results of the field review, the yard of the traditional house of Bayung Gede Village has its own characteristics. Bayung Gede Village does not adhere to the sanga mandala pattern, but the residential pattern adheres to the same concept as the settlement pattern, namely "upstreamteben". The upstream-teben concept consists of: (1) sanggah located in the upstream (main); (2) the kitchen (paon) and sa fety bale (bedroom) are located in the middle (madya); and (3) the barn/jineng is located in the teben (nista) section.

The diversity of the layout of the Bayung Gede residence, starting from the entrance of the house (angkul-angkul) in each house, is influenced by the position of the road in this village environment. The neighborhood road in Bayung Gede Village is the orientation of the angkul-angkul/doors for entry and exit of the house.

\section{Typology of Residential Yard in Bayung Gede Village}

The phenomenon of typology of residentialyards in Bayung Gede Village has unique characteristics in terms of setting the location of each building. The typology of the yard of this village residence, where the road is the key in determining the location of the entrance and exit of the house. There are 2 types of roads, namely:

- The road section that extends from north to south

It can be seen in Figure 19, based on the orientation of the road segment, there are two types of housing positions, which are located on the east side of the road and the west side of the road. Each residential house starts from the disgraceful/teben zone, namely the angkul-angkulas the entrance, then the middle zone, namely the kitchen and bedroom, and the main/holy zone, namely the sanggah. The house on the east side of the road, the location of the objection is in the west, while the house on the west side of the road, the location of the objection is in the east.

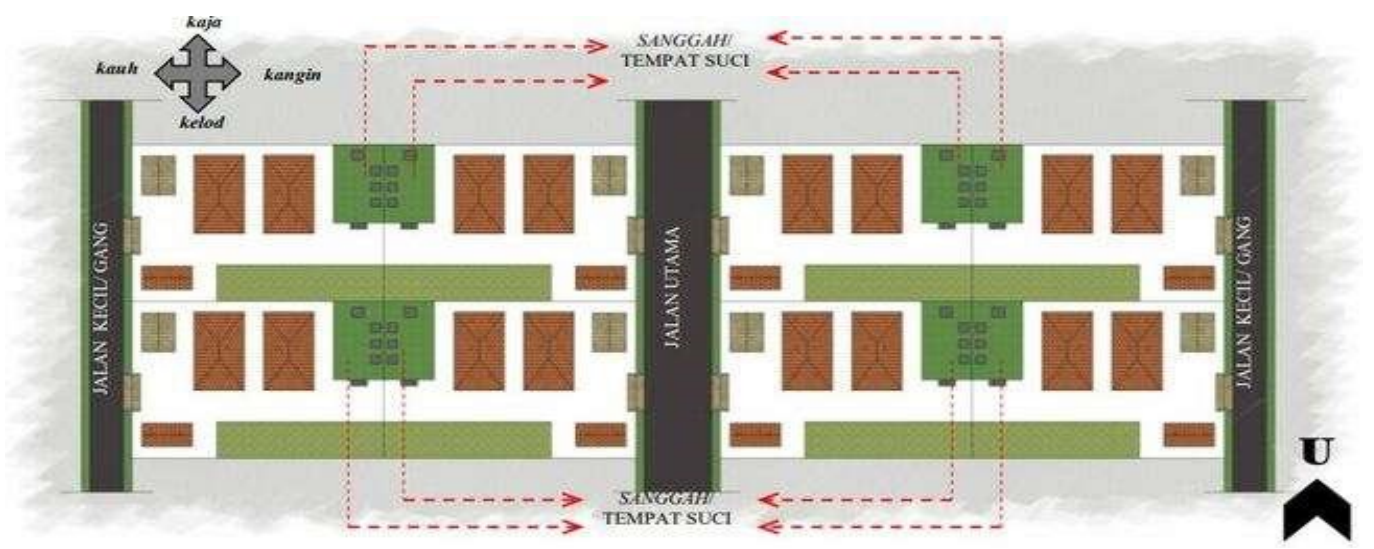

Figure 19. Home Yard Layout for North-South Direction. Source: Widiyani, 2020

Description:

1. Sanggah/Sacred place: Pura

2. Main Street

3. Small Street/Alley

- The road that extends from east to west

It can be seen in Figure 20, based on the orientation of the road segment, there is one type of residential house position, which is towards the south with the stand on the east side. 


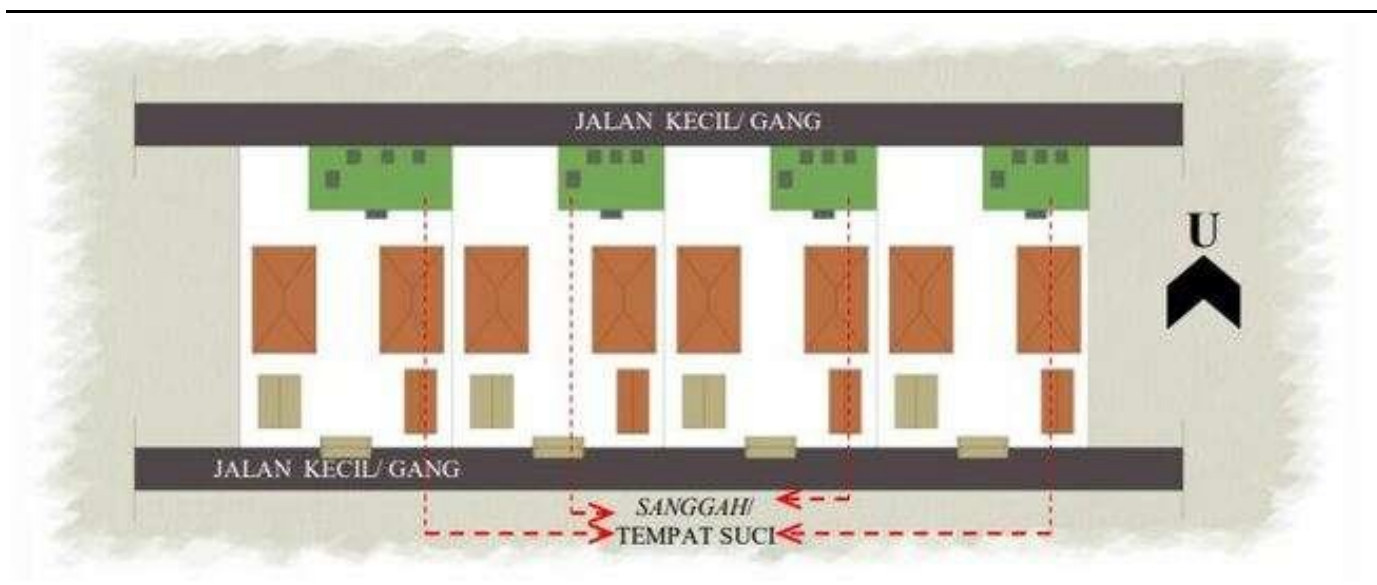

Figure 20. Layout of Residential Yard in East-West Direction. Source: Widiyani, 2020

Description:

1. Residential House of Bayung Gede Villager

2. Small Street / House Alley

Based on the description above, it can be concluded that there are 3 types of typology in the yard of the Bayung Gede Village house based on the orientation of the road. When viewed from the main/sacred zone, namely the sanggah, it is proven in this village that the location of the sanggah in the yard of the house is not always in the north-east which is the sacred zone. This spatial arrangement becomes unique and essential if it is associated with the configuration of the argument based on the concept of Traditional Ba linese Architecture.

\section{Concepts Affecting the Layout of the Yard of the Bayung Gede Village Residence}

It can be seen in Figure 21 that the layout of Bayung Gede's yard does not adhere to the sanga manda la concept, but adheres to the "upstream-teben" concept. The concept of upstream teben is a concept that regulates space zones based on the level of its sacred/sacred value. A mountain where the height is made upstream/north as a sacred/main zone, then teben/sea direction is the opposite of the direction of the mountain being used as a teben or low/disgusting zone.

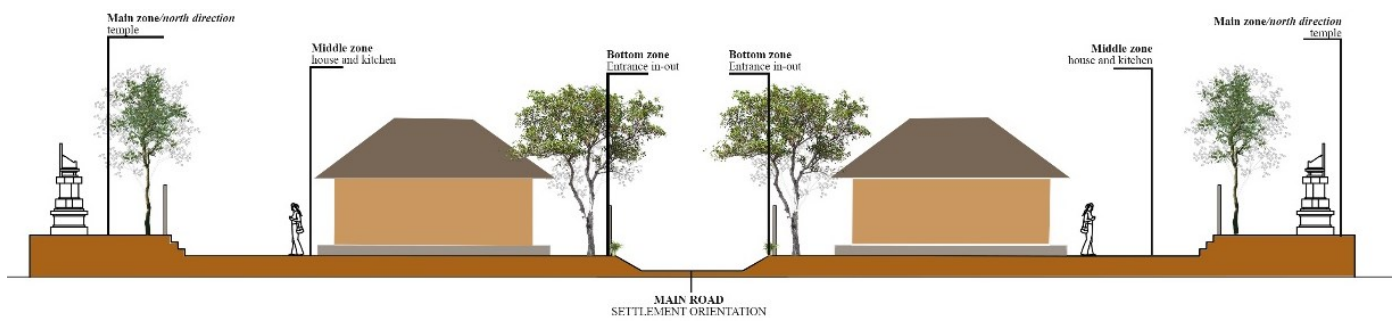




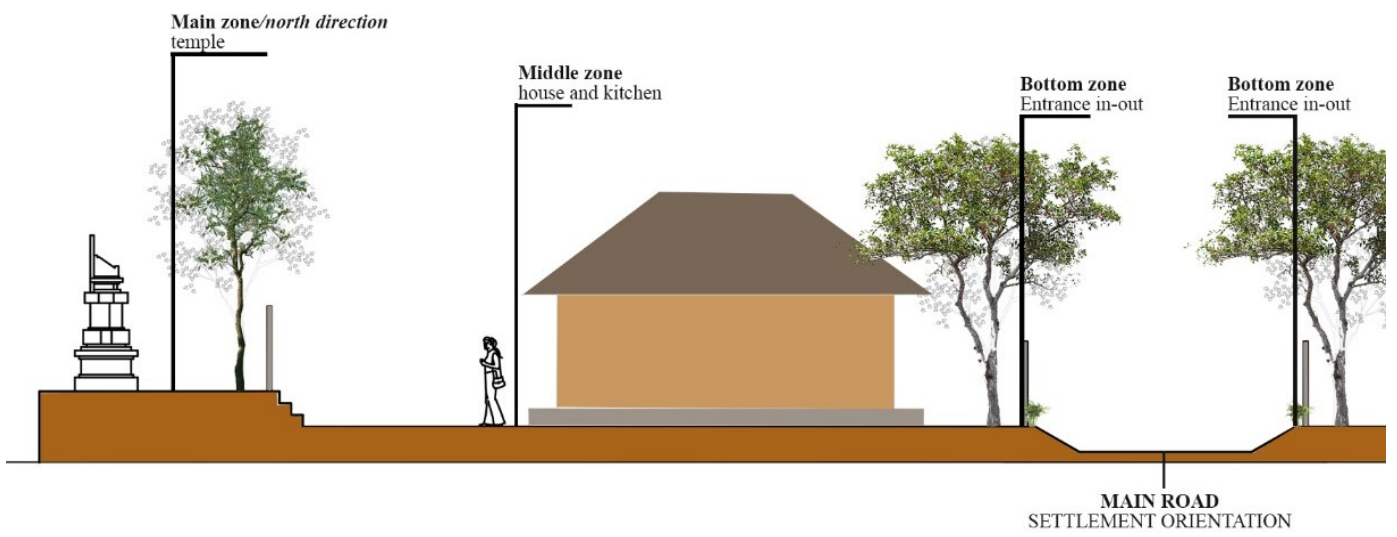

Figure 21. The concept of "Hulu-Teben" in the yard of the Bayung Gede Village. Source: Vianthi, 2020

Based on the picture above, where the concept is applied in the difference in height/level for each building mass. Starting from the sanggah, which is the main zone (upstream) which has the highest position from the yard, then the kitchen and building as a resting place (midya zone) have a lower position than the sanggah, but higher than the angkul-angkul (entrance) and angkul-angkul as the main zone. the entrance-exit has the lowest notch (zone of humiliation/teben). Apart from adhering to the "upstream-teben" pattern, this village is also based on the Tri Mandala concept, namely (1) Sanggah as the main mandala; (2) paon and sa fety bale as middle mandala; and (3) the outermost parts such as jineng and angkul-angkulas a scathing mandala.

\section{Component 4A Settlement in Bayung Gede Village as a Tourist Attraction}

The Tourism Component 4A according to Cooper, et al (1995) in Setyanto and Pangestu (2019) consists of Attractions, Amenities, Accessibility and Additional Services. The following can be seen in Table 4 which is a description of the $4 \mathrm{~A}$ component in the Bayung Gede TraditionalVillage as a special interest tourist attraction.

Table 4. Component 4A Settlement in Bayung Gede Village as DTW

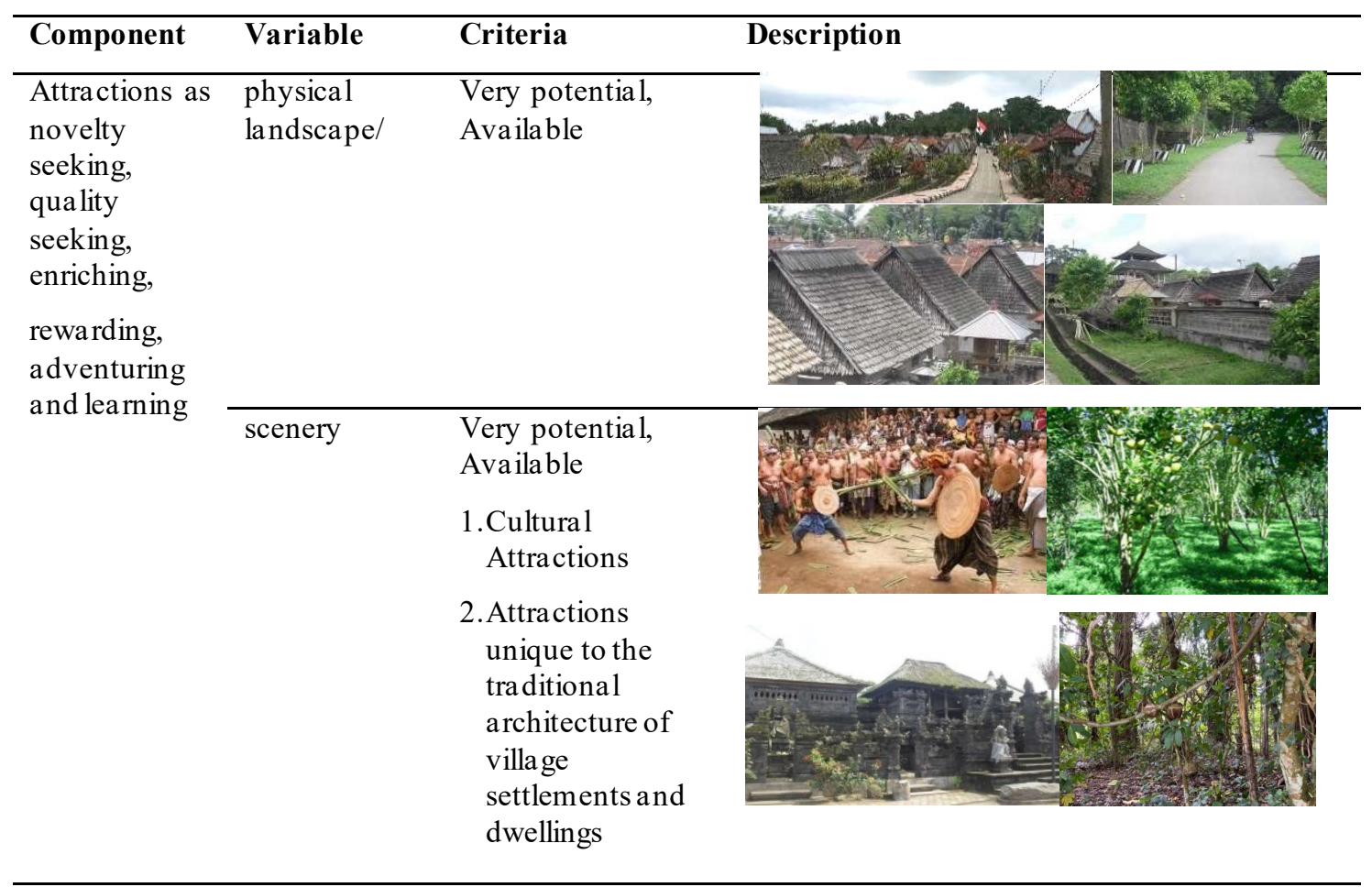




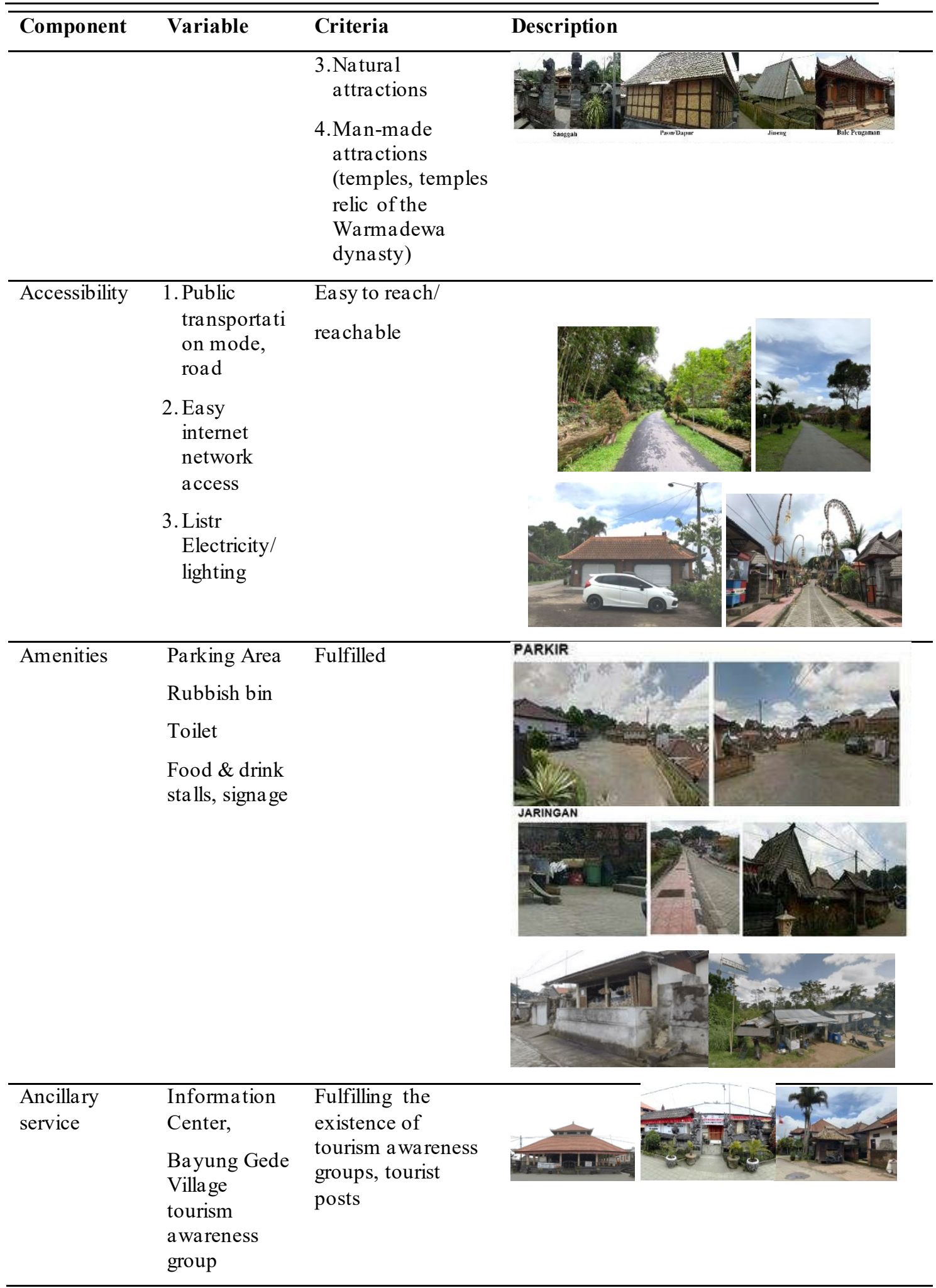

Source: analysis results, 2021

Architectural Elements (Spatial Layout) of Bayung Gede Village Settlement as Special Interest Tourism 
According to Tha lia (2011) states that the shift in tourism interest gave birth to the development of susta inable tourism through the development of special interest tourism, which is a tourism pattem that emphasizes greater appreciation and appreciation for the preservation of nature, the environment, and culture (enviromentally and culturally sensitives). According to Widhiarini, Oktaviani \& Permanita (2019), special interest tourism is a travel activity that is driven by 6 motivations, namely (1) Novelty Seeking: the desire to find something unique; (2) Qua lity Seeking: the search for quality experiences; (3) Rewarding: appreciation for an object; (4) Enriching: increasing knowledge; (5) Adventuring: an adventurous experience and (6) Learning: following the learning process on an activity being carried out.

The following can be seen in Table 5 which is a description of the special interest tourism elements contained in architectural components such as residential spatial planning, spatial planning and building conditions as well as the activities of Bayung Gede Village residents.

Table 5. Architectural Elements as Special Interest Tourism in Bayung Gede Village

\begin{tabular}{|c|c|c|}
\hline \multicolumn{2}{|c|}{ Architectural Elements of Settlements } & Potential Tourist Attractions \\
\hline \multirow{9}{*}{$\begin{array}{l}\text { Residential } \\
\text { Layout } \\
\text { as a supporter of } \\
\text { elements of } \\
\text { novelty seeking, } \\
\text { quality seeking, } \\
\text { enriching, } \\
\text { adventuring and } \\
\text { learning }\end{array}$} & $\begin{array}{l}\text { Balinese Traditional } \\
\text { Settlement Linear } \\
\text { Pattern }\end{array}$ & $\begin{array}{l}\text { 1. Provide unique and a ttractive visuals } \\
\text { 2. Able to provide knowledge related to traditional } \\
\text { Balinese philosophical settlement patterns (Tri Hita } \\
\text { Karana) }\end{array}$ \\
\hline & Telajakan & 1. Provide unique, beautiful and attractive visuals. \\
\hline & \multirow[t]{3}{*}{$\begin{array}{l}\text { Balinese Traditional } \\
\text { Settlement }\end{array}$} & $\begin{array}{l}\text { 2. Be able to provide a philosophical understanding of } \\
\text { the telajakan as a tra ditionalBa linese landscape } \\
\text { architecture. (Tri Hita Karana) }\end{array}$ \\
\hline & & $\begin{array}{l}\text { 3. Able to explain knowledge related to planted } \\
\text { vegetation and the purpose of planting it. }\end{array}$ \\
\hline & & $\begin{array}{l}\text { 4. Provide an explanation regarding the function } \\
\text { telajakan }\end{array}$ \\
\hline & \multirow[t]{4}{*}{$\begin{array}{l}\text { Rows of } \\
\text { Kori/angkul-angkul } \\
\text { Resident's House }\end{array}$} & $\begin{array}{l}\text { 1. Provide beautifuland attractive visuals. } \\
\text { 2. Able to provide a philosophical understanding of the } \\
\text { architectural form of Kori (Entrance) in the Bayung } \\
\text { Gede Village Settlement }\end{array}$ \\
\hline & & $\begin{array}{l}\text { 3. Able to provide knowledge related to construction } \\
\text { and its constituent materials (Asta Kosala-Kosali) }\end{array}$ \\
\hline & & $\begin{array}{l}\text { 4. Provide an explanation regarding the function of } \\
\text { Kori (Outside the general entrance / main village } \\
\text { gate) }\end{array}$ \\
\hline & & $\begin{array}{l}\text { 5. Able to provide knowledge related to the application } \\
\text { of ornaments or ornaments that compose it (Asta } \\
\text { Kosala-Kosali) }\end{array}$ \\
\hline \multirow{3}{*}{$\begin{array}{l}\text { SpatialPlanning } \\
\text { and Building } \\
\text { Conditions for } \\
\text { Residents' } \\
\text { Houses as } \\
\text { supporting } \\
\text { elements of }\end{array}$} & \multirow{3}{*}{$\begin{array}{l}\text { SpatialLayout } \\
\text { "hulu-teben" pattern } \\
\text { in the yard of the } \\
\text { house }\end{array}$} & 1. Provide unique, beautifuland attractive visuals. \\
\hline & & $\begin{array}{l}\text { 2. Able to provide a philosophical understanding of the } \\
\text { layout of the house with the concept of "hulu-teben"/ } \\
\text { Home Page (Tri Hita Karana, Tri Mandala) }\end{array}$ \\
\hline & & $\begin{array}{l}\text { 3. Able to explain knowledge related to vegetation that } \\
\text { can be planted on the home page }\end{array}$ \\
\hline
\end{tabular}




\begin{tabular}{|c|c|c|}
\hline \multicolumn{2}{|c|}{ Architectural Elements of Settlements } & Potential Tourist Attractions \\
\hline \multirow[t]{10}{*}{$\begin{array}{l}\text { novelty seeking, } \\
\text { quality seeking, } \\
\text { enriching, } \\
\text { adventuring and } \\
\text { learning }\end{array}$} & $\begin{array}{l}\text { Traditional Ba linese } \\
\text { Architectural Style } \\
\text { (Original) }\end{array}$ & $\begin{array}{l}\text { 1. Provide beautifuland attractive visuals. } \\
\text { 2. Able to provide a philosophical understanding of the } \\
\text { architecturalstyle of the house in the Bayung Gede } \\
\text { Village Settlement }\end{array}$ \\
\hline & & $\begin{array}{l}\text { 3. Able to provide knowledge related to the application } \\
\text { of ornaments or ornaments that compose them (Asta } \\
\text { Kosala-Kosali) }\end{array}$ \\
\hline & $\begin{array}{l}\text { Traditional Ba linese } \\
\text { Architectural Style } \\
\text { (Renovation) }\end{array}$ & $\begin{array}{l}\text { 1. Provide beautifuland attractive visuals. } \\
\text { 2. Able to provide a philosophical understanding of the } \\
\text { architecturalstyle of the house that has been } \\
\text { renovated with another tra ditionalBalinese style in } \\
\text { the Bayung Gede Village Settlement }\end{array}$ \\
\hline & & $\begin{array}{l}\text { 3. Able to provide knowledge related to the application } \\
\text { of ornaments or ornaments that compose them (Asta } \\
\text { Kosala-Kosali) }\end{array}$ \\
\hline & $\begin{array}{l}\text { The Presence of } \\
\text { Traditional } \\
\text { Buildings (Jineng, } \\
\text { Paon, Bale, } \\
\text { Sanggah) }\end{array}$ & $\begin{array}{l}\text { 1. Provide unique, beautifuland attractive visuals. } \\
\text { 2. Able to provide a philosophical understanding of the } \\
\text { Bale Architectural Style or sacred/refuted buildings } \\
\text { in the Bayung Gede Settlement }\end{array}$ \\
\hline & & $\begin{array}{l}\text { 3. Able to provide knowledge related to construction } \\
\text { and its constituent materials (Asta Kosala-Kosali) }\end{array}$ \\
\hline & Traditional Balinese & 1. Provide unique, beautifuland attractive visuals. \\
\hline & & $\begin{array}{l}\text { 2. Able to provide knowledge related to construction } \\
\text { and its constituent materials (Asta Kosala-Kosali) }\end{array}$ \\
\hline & & $\begin{array}{l}\text { 3. Provide a philosophy of determining proportions } \\
\text { (asta kosala-kosali) }\end{array}$ \\
\hline & $\begin{array}{l}\text { Functional Aspects } \\
\text { of Traditional } \\
\text { Balinese Buildings }\end{array}$ & $\begin{array}{l}\text { Provide a philosophical explanation regarding the } \\
\text { function of each building (tri hita karana, tri mandala, } \\
\text { etc.) }\end{array}$ \\
\hline $\begin{array}{l}\text { Citizen Activities } \\
\text { as the application } \\
\text { of the elements } \\
\text { of Adventuring, } \\
\text { Enriching and } \\
\text { Learning }\end{array}$ & $\begin{array}{l}\text { Citrus, coffee and } \\
\text { corn plantations as } \\
\text { an increase in the } \\
\text { a gricultural sector in } \\
\text { the settlements of } \\
\text { Bayung Gede } \\
\text { Village }\end{array}$ & $\begin{array}{l}\text { Can be an accommodation for tourists as well as provide } \\
\text { direct experience in the daily activities of residents }\end{array}$ \\
\hline
\end{tabular}

Source: analysis results, 2021

\section{CONCLUSION}

Based on the results of the study, the architectural components of the Bayung Gede Village settlement as a potential to support special interest tourist attractions, such as novelty seeking, quality seeking, enriching, adventuring and learning are contained in the Bayung Gede Village settlement. This is evidenced by the unique linear pattern and the "upstream-teben" residential pattern of the Bayung Gede Village settlement which is the hallmark of this village, then the existence of eight Pertiwi Temples as relics of the Warmadewa dynasty; a unique accessibility system that is different from others, something unusual in the arrangement of traditional villages in 
Bali, namely the incoming circulation from the direction of Hulu/Kaja/North and heading to Teben/Kelod; the uniqueness of elements of traditional settlements with the presence of four types of graves (setra placenta, setra rare/children, setra gede/adults and setra pengancab); the uniqueness of the variants of residential layout (spatiallayout and condition of the house) such as angkul-angkul, jineng, paon, safety bale and sanggah and no less important is the daily activities of residents (plantation) namely citrus gardening activities in improving the plantation or agriculture sector in Bali, especially Bangli as the center of citrus production in Bali, so it can be concluded that the traditionalarchitectural components of the Bayung Gede Village Settlement have the potentialasa special interest tourist destination as a supporter of sustainable tourism development.

\section{REFERENCES}

Adhika, I. M., \& Putra, I. D. G. A. D. (2021). Reinvigorating cultural landscapes for planning cultural tourism in Bali. Geojournal of Tourism and Geosites, 33(4), 1462-1469. https://doi.org/10.30892/gtg.334sp103-594

Ayu Natih, dkk. 2019. Arsitektur Tradisional Bali pada Bangunan Puri sebagai Daya Tarik Wisata da lam Mendukung Pengembangan Pariwisa ta Berkelanjutan di Bali. PUSAKA: Journal of Tourism, Hospita lity, Travel and Business Event. Vol. 1. No. 2. Hal. 46-52. (Indonesian).

Aritama, A. A. N., \& Putra, I. D. G. A. D. (2021). Tourism Activities in the Traditional Balinese House: The Challenges of Designing a Homestay in Gianyar Bali. Journal of Social and Political Sciences, 4(1). https://doi.org/10.31014/aior.1991.04.01.250

Banglikab. 2014. Peraturan Da erah BupatiBangli Nomor 16 Tahun 2014. Bangli. (Indonesian).

Basset, Keith \& Short, John, 1980. Housing and Residential. Structure, Alternative Approaches. London: Routledge \& Kegan Paul Ltd.

Dewa Gede Agung Diasana Putra, I. (2019). The Disproportional Arrangement of the House: The Biodiversity Spaces and the Transformation of the Tra ditionalBalinese House in Tourism Economy. In Tourism - Perspectives and Practices. https://doi.org/10.5772/intechopen.81989

Dwijendra, N. K. A. (2009). Arsitektur dan Kebudayaan Bali Kuno. Udayana University Press dan CV Bali Media Adhikarsa.(Indonesian).

Dwijendra, N. K. 2003. Perumahan dan Permukiman Tradisional Bali. Jurnal Permukiman "NATAH" Vol.1 No.1, 8-24. (Indonesian).

Gede Wijaya A.A. 2008. Pengembangan Desa Wisata Tenganan Pegringsingan di Desa Tenganan Kecamatan Manggis Kabupaten Karanga sem. Tesis S2 Kajian Pariwisaa Unud. (Indonesian).

Gelebet, I Nyoman. dkk. 1986. Arsitektur Tradisional Daerah Bali. Denpasar: Departemen Pendidikan dan Kebudayaan Proyek Inventarisasi dan Dokumentasi Kebudayaan Daerah. (Indonesian).

Gelebet, I Nyoman, 1988.Arsitektur Tradisional Daerah Bali. Depddikbud. (Indonesian).

Manik, Yuda.2007. Pengaruh Demografi, Gaya Hidup, dan Aktivitas Terhadap Transformasi Tipo Morfologi Hunian Tradisional di Desa Bayung Gede, Bali. Tesis Arsitektur ITB. (Indonesian).

Putra, I.D.G.A. 2003. Konsepsi Dan Makna ArsitekturTradisional Pada Bangunan Kekinian Se buah Intepretasi Masyarakat LokalBali Tengah Pada Transformasi Rumah Tradisional. Vol. 1 No. 1, 1 21 - 1-30. (Indonesian).

Parimin, A. P. (1986). Fundamental study on spatial formation of island village: environmental hierarchy of sacred-profane concept in Bali. 大阪大学.

Putra, I.D.G.A. 2015. The Impact of Tourism on the Tranformation of the Traditional Balinese House. Unpublished PhD Thesis, Deakin University, Australia. 
Putra, I. D. G. A. D., Lozanovska, M., \& Fuller, R. (2019). From spiritualistic toward more pragmatic pattern: Re-ordering Balinese houses and viability of the household traditions in tourism economy. Journal of Architecture and Urbanism, 43(1). https://doi.org/10.3846/jau.2019.3692

Putra, I. D. G. A. D., Wirawibawa, I. B. G., \& Satria, M. W. (2020). Spatial orientation and the patterns of the traditional settlement in the eastern Bali: Investigating new tourism atractions. Geojournal of Tourism and Geosites, 29(2). https://doi.org/10.30892/gtg.29218-493

Reuter, T. (2002). The house of our ancestors: precedence and dua lism in highland Balinese society. Brill.

Reuter, T. A. (1996). Custodians of the sacred mountains: The ritual domains of highland Bali.

Sangadji, E. M., \& Sopiah. (2010). Metodologi Penelitian: Pendekatan Praktis dalam Penelitian. Yogyakarta: ANDI. (Indonesian).

Sedarmayanti, Sa strayuda, G. S., \& Afirza, L. (2018). Pembangunan dan Pengembangan Pariwisata. Bandung: Refika Aditama. (Indonesian).

Setyanto, I., \& E. P. (2019). Pengaruh Komponen Destinasi Wisata (4A) Terhadap Kepuasan Pengunjung Pantai Gemah Tulungagung. Jurnal Administrasi Bisnis, Volume 72 No 1, 157-167. (Indonesian)

Siwalatri, Ni Ketut Ayu. 2014. Makna Sinkronik Arsitektur Bali Aga di Kabupaten Buleleng Bali. (Indonesian).

Sugianto, A. (2016). Kajian Potensi Desa Wisata Sebagai Peningkatan Ekonomi Masyarakat Desa Karang Patihan Kecamatan Balong Ponorogo. JurnalEkuilibrium Vol.11 No.1, 56 -65. (Indonesian).

Swanendri, N. (2017). Transformasi Rumah Tinggaldan Pola SpasialPermukiman MasyarakatBali Aga Desa Pekraman Timbrah, Desa Pertima, Kecamatan Karangasem, Kabupaten Karanga sem. Denpasar. (Indonesian).

Syamsul Alam Paturusi. 2017. Permukiman Bali Kuno Desa Bayung Gede sebagai Atraksi Pariwisata di Bali. Seminar Nasional Arsitektur dan Tata Ruang. Hal. 4-57 - 4-66. (Indonesian).

Widhiarini, N. N., Oktaviani, P., \& Permanita, N. D. (2019). Arsitektur Tradisiona; Bali Pada bangunan Puri Sebagai Daya Tarik Wisata Minat Khusus Dalam Mendukung Pengembangan Pariwisata Berkelanjutan. PUSAKA: Journal of Tourism, Hospitality, Travel and Business Event Vol.1, No.2, 46-52. (Indonesian).

Windu, Gede Laskara.2008. Arsitektur Vernakuler Desa Bayung Gede, Bangli. (Indonesian).

Widiastuti, S. A. Paturusi, dkk. (2017). Perubahan Arsitektur Tradisional Hunia Desa Bayung Gede, Bangli. Seminar Na sional Arsitektur dan Tata Ruang. Ha1. 3-109 - 3-1 19. (Indonesian). 